Historic, Archive Document

Do not assume content reflects current scientific knowledge, policies, or practices. 

62.23

ध20.

EBER SEED CO.

1928

CATALOG

=of

High Class Seeds and Bulbs Garden Implements, Etc.

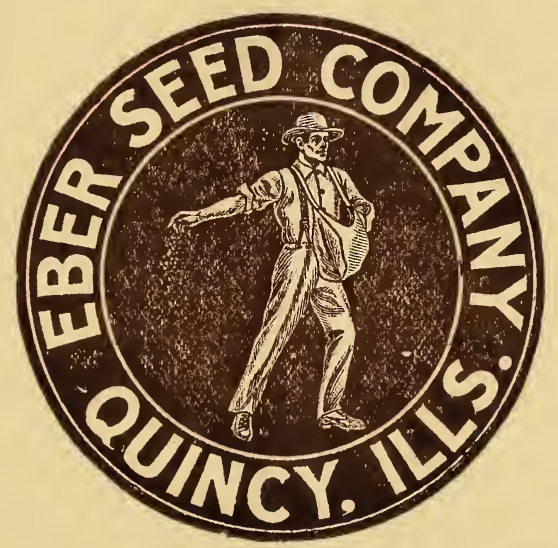

Sixth and Vermont Streets QUINCY, $\because:$ ILLINOIS 
E THANK our many friends and customers for their kind patronage which they have given this firm for so many years past, and hoping to receive their future patronage-which will at all times have the best, prompt and most careful attention.

We would respectfully suggest to give the reading matter of this catalogue careful perusal. We are giving the purchaser the value in seed, and not in pictures. It is interesting and useful reading for the farmer, for the gardener, and amateur raiser of flowers. Should you, however, not be interested, please hand it to your neighbor, who may be. No doubt, most anyone will find something of interest.

\section{ORDERS}

Orders should be written on our order sheets or on a blank sheet separate from letter, preferably in ink. Write name and post office address distinctly. All orders, large or small, receive prompt attention.

\section{SEED BY MAIL}

Our prices include postage on all vegetable and flower seeds, by the packet, ounce or pound. Five cents per pound and one cent for each additional pound should be added to catalogue prices on beans, peas, corn, and bulbs-if wanted by mail.

\section{PRICES}

Our first consideration and constant aim is to offer the highest class seed procurable, and the next is to put our prices as low as good, reliable seed can be sold. We feel assured in saying that there is no occasion for any one to send away money for goods in our line, which you can get at home at the right price, and what is more, the best of quality, besides you have the satisfaction of aiding home industry.

We feel assured in saying that the seeds we offer cannot be surpassed by ANY, and will give entire satisfaction if proper treatment is bestowed. It sometimes happens that seeds of unquestionably good quality fail to germinate or grow to perfection for want of timely and proper treatment or unfavorable weather, and it must be distinctly understood that we give no warranty, express or implied, as to description, quality, productiveness, or any other matter of seeds, bulbs, or plants we send out, and we will not be in any way responsible for the crop. If the purchaser does not accept the goods on these terms, they are at once to be returned.

\section{EBER SEED COMPANY QUINCY, ILL.}

234-236 Sixth Ave. N. 


\section{Directions for Cultivating Vegetables}

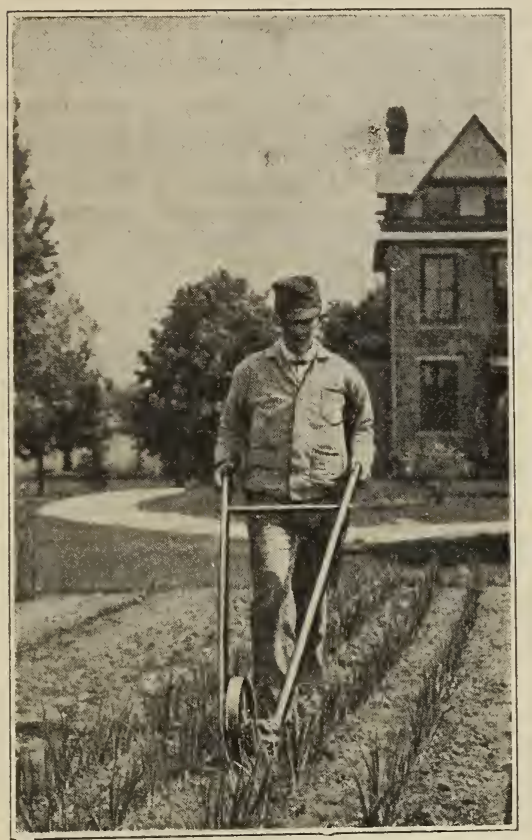

T SECURE a good crop of vegetables, three things, at least, are necessary, viz: A Suitable Soil, Pure Seed, and Clean Culture, to which may be added as equally necessary, an abunilant supply of good, Barn-Yard Manure, supplemented when this runs short, by artificial fertilizers. The exposures for a vegetable garden should be, preferable, south or southwest, or nearly so. The soil should be naturally fertile and friable, a sandy loam being always the best. If the soil be stiff, it should be gradually mellowed by the free use of barn-yard manure, or, if convenient, by the addition of sand. If wet, or inclined to hold an excess of moisture, it should be underdrained, pre ferably by tile; but if possible, a location should be selected that is naturally dry and free from surface water.

A dark colored soil, or one supplied with a goodly portion of decayed vegetable matter, will produce the earliest crops. If the soil is shallow, it should be deepened gradually by plowing or spading an inch or two deeper each year and not all at once by trenching or subsiding. unless manure and money are both abundant. A sanḋy soil may be greatly improved by adding more or less vegetable mould from the woods. To produce the best and uniform results the vegetable garden should have at least one foot of good, rich soil. The roots of large trees should not be allowed to encroach any part of the garden, though large trees, especially evergreens, sufficiently far off, afford a valu-

able protection from the north and west.

Mark the garden off into squares or beds of convenient size, to facilitate the practice of rotation of crops, which is an important matter. As a rule, never let the same crop or kind of vegetable occupy the same bed or spot two years in succession. Potatoes and few other things may form an exception to this rule, but is nevertheless better to keep up rotation. Every year these beds must he warmed up by a liberal coat of manure, which should be thoroughly mixed with the soil. Grow everything in drills or straight lines, not even excepting corn and potatoes. Larger crops from a given surface are grown in this way, and cultivation becomes simple and comparatively easy. The space between the drills and other special information are given in the body of this catalog. The least distance is named in order to economize space. It might be in creased in some cases with advantage. The ground should be frequently hoed to kill the weeds and keep the soil mellow; the proper time to hoe is just when the weeds appear above the ground. Briefly, the proper way to kill weeds is never to let them grow. If the weeding is done at the time suggested, it can be effectually and quickly done by the use of a sharp-toothed steel rake.

Soil working instruments are a real neces. sity in practicing the art of gardening econ omically. Seeding by hand is excessively slow, uncertain and unsatisfactory, because of irregularity. Up-to-date machines plant the seed accurately in a straight narrow line. Cultivators and Wheel Hoes stir and mix the soil, cut out every weed below the surface between the rows and maintain a fine loose earth mulch, about an inch deep over the entire plot. These tools do all that can be done to the ground better, easier and at least expense than by the old system of hand labor. Once used, always used.

We have a full and complete stock of the above instruments. See Pages $38,39,40$.

The freshest seeds of some kinds often fail from unseasonable and improper management in sowing and other circumstances affecting their vegetation. When sown too early or too deep, while the ground is too cold, wet and heavy, they are apt to rot; when sown too shallow, in dry time and late in the season, there may not be sifficient moisture to sprout them, or they may have dried up by dry winds or a hot sun after they have germinated. Sometimes insects destroy them before or immediately after their appearance above the ground so that the complaints occasionally made by the in. experienceá, are not always to be attributed to the quality of seed. Instructions in this book are ample, and when they are read and followed up, ninety-nine out of one hundred have no reason to blame the seed. 


\section{MAKING A HOT-BED}

As the use of hot-beds is of undoubted advantage, derived by early starting of vegetables, we append directions for making them.

To prepare a hot-beả, a quantity of stable manure should be well shaken up in a heap, about the beginning or middle of February; after remaining three days, it should be shaken up and turned over again in another interval of three days. Let the manure remain for three or four days more in a heap, and then form the bed of any dimensions that may be requisite, according to size or number of frames to be used, making the bed about a foot wider than the frame all around. The bed, when made, should not be less than three feet high; the situation for it should be dry underneath, sheltered from the north as much as possible, and fully exposed to the sun. In making up beds, beat the manure well down with the fork. Place about eight inches of light, rich soil in the frame, after it is placed on the bed, so that the surface of the soil may be from six to eight inches from the top of the frame. After the bed has stood with the lights on, but raised a few inches to let the steam escape, for a few days, sow the seed of Cabbage, Tomatoes, Cauliflower, Egg Plant, Celery, Lettuce, Radish, etc., etc. When the plants make their appearance above the ground, give some air day and night, in moderate weather, by raising the lights two or three inches-and as the heat of the bed diminishes, increase the supply of air to prevent the plants being drawn up. In severe weather, the frame and lights should be covered at night with mats or boards. In high wind also protect the size of the bed in the same manner or the current of air will extinguish the heat of the bed. If made early in the season, water only will be required when the earth in the frame becomes quite dry; as the plants increase in size, the supply of water may be increased. In frost or cold weather the water should be made milkwarm before it is used; this is important.

SOWING SEEDS-Warmth and moisture are essential and seclusion from light is favorable to germination. The first care in sowing seeds should be to choose suitable ground, the proper season and state of earth, and then to place them at such depth beneath the surface as will insure the requisite supply of moisture. In general, all seeds should be covered more or less, according to their size and the advance of the season, late sowing requiring to be covered the deepest. The smallest seeds should be sown very shallow in fine earth and rolled or beaten firmly with the back of the spade.
THINNING OUT-Next to errors of too deep or too shallow sowing of seeds are the errors of thick seeding without correspond. ing thinning and to let the plants get too large.

It is far better to thin out a row of beets, lettuce, carrots or parsnips so as to obtain good specimens at proper distances, than crowding together at half an inch apart, as is often seen in the gardens of the inexperienced. So clearly evident is the advantage of thinning out, that we will not waste space dwelling upon it, other than to give the following table of suggestive distances to which veegtables in the private garden should be thinned.

1 inch-Radishes.

2 inch-Beans, carrots, peas, salsify, corn, salad.

3 inches-Beets, kale, onions, parsnips, spinach, turnips.

5 inches-Endive, parsley.

6 inches-Lettuce, okra.

TRANSPLANTING-Is an important feature in gardening operations, an done often improperly done. Transplant toward even. ing; make a hole sufficient large to hold the plant; fill with water and puddle the plant in; then press the soil firmly around the plant. Afterwards cover with dry soil and the plant will never drop, it matters not how warm or sunny the day may be. It may be argued that this is not practicable with large fields of cabbage, cauliflower or tomatoesbut the best way is always the most practical, consequently the cheapest. It is economy to devote a day to a work, and have the plants all thrive and live, than to put them out in one-fourth of the time and have a large portion die and the remainder only half alive.

IN DRY WEATHER it is of great impor. tance to FIRM and TREAD the soil after the seed is put in. Seed sown in this manner will readily germinate and grow, while otherwise the result will be doubtful. This precaution should not be overlooked in sow. ing very small or light seed. Moist ground needs no firming.

INSECTS OF ALL KINDS are troublesome and sometimes very destructive. Plaster of Paris, snuffs, ashes, or soot sifted on cucumbers or squashes, when wet with dew, is very useful against the striped bug. Lime, road-dust, ashes or snuffs, scattered over young cabbage or turnips will sometimes prevent the ravages of the black fly. Rolling the ground after sowing answers a good purpose; but the best preventatives is a thorough sprinkling of the plants in the evening with whale oil soap suds, in proportion of one pint of soap to seven and a half gallons of water. This will kill cabbage lice and all other aphides. It is sure death to all tender insects, when forcibly applied with a garden sprayer. For the want of whale oil soap, strong soft soap suds may be used. Salt is sometimes sown in the drills with onion seed to drive away the grub. Fine salt or Slug Shot strewn broadcast over the cabbage is the best application we know of for destroying the little green cabbage worms and maggots. 


\section{SEEDS OF SPECIAL MERIT}

BEANS Old Homestead, or Kentucky Wonder-The most popular large podded pole beans; it bears in clusters and in pods, is seven to eight inches in length: unusually prolific and very tender.

Bountiful-Large-sized, broad green and tender pods, stringless, very productive and fine quality.

Full Measure-A very desirable, round-podded variety with pods six to seven inches long, which are solid, meaty, brittle and stringless. It is but a little later than Stringless Green Pod and is a splended Bean for home or market use.

Burpee's Improved Bush Lima-An improved strain of Burpee's Bush Lima, having much larger pods and beans.

BEETS New Model Beet-The finest table variety of all; tender, solid and crisp flesh; of fine flavor. The color is dark blood-red: almost gobular in shape.

Detroit Dark Red-One of the best red turnip varieties. Has small, upright tops; splendid shape; color of skin is dark blood-red; flesh deep, bright red. Very crisp, tender and sweet; matures early and keeps in good condition for a long time.

Early Wonder-A selection from Crosby's Egyptian, though not so early as our strain of that variety. Roots very uniform, nearly globe-shaped, with small top and tap root; skin dark red, flesh deep blood red, with little zoning. Popular with market gardener for early or late planting. $\underline{C A B B A G E}$ The Golden Acre-A new sort, about one week earlier than the Copencan be planted closer in the rows.

New Early Cabbage, Copenhagen Market-Undoubtedly the finest, large round-headed early Cabbage. The heads average about ten pounds each in weight, are very solid and of fine quality. It matures as early as Charleston Wakefield, and will give a heavier yield per acre than that well-known variety. The plant is short-stemmed, the leaves light green, rather small, and always tightly folded. The plants, therefore, can be set closer together than is usual with varieties of similar size.

CAULIFLOWER Large Early Snowball-short stem; finest strain. It is one of the best for forcing under glass or for open ground.

CELERY Giant Pascal and Golden Heart-Best celery for the market gardener and general use. Productive, tender, sweet and crisp.

SWEET CORN, Charlevoix-An early or intermediate, yellow grained sweet corn of distinctive merit. Ear's about seven inches long. usually twelve rowed, and when in condition for use are light creamy in color. The grain is rather short, very sweet and tender, and is unsurpassed in quality. In seàson it is a few days later than Golden Bantan, but remains in condition much longer than that variety. An excellent sort, both for the home and the market garden.

Golden Bantam-Very early, can be planted a little earlier than other corn on account of its hardness. Ears are about 6 to 7 inches long, filled with broad, sweet, golden yellow kernels.

Alpha-The earliest sweet corn. Matures a week earlier than the White Cory. Ears aver. age six to seven inches long, uniform, and quality fully equal and tender as the White Cory. 
CUCUMBER The Longfellow is a White Spine type with an admixture of Emerald blood, from which it gets its intense, dark-green appearance. The vines are exceptionally healthy and productive, and fairy early. The fruits will average 12 to $14 \mathrm{in}$. in length by $2 \frac{1}{2} \mathrm{in}$. in diameter, and are very symmetrical. The color is all that could be desired, and this variety will retain its dark-green color when shipped to distant markets. An ideal type for the private garden or as a "straight pack" variety for shipment, boxed, to high grade markets.

Rice's Early Fortune Cucumber-The vines make a strong and vigorous growth, producing. abundant crops of Cucumbers, which are slightly longer than Arlington White Spine, more cylindrical in shape, and have a very dark green skin. The flesh is thick, seed cavity relatively small, and the quality is excellent. This variety is one of the best introduced in years. LETIUCE $\begin{aligned} & \text { Wonderful-Large white head resembling cabbage, very } \\ & \text { solid, crisp, rich and tender. }\end{aligned}$

Iceberg-Large, solid, curled head, yellow heart, crisp and tender.

ONIONS Valencia or Sweet Spanish-An improved prize-taker, very large, sweet and 

PEPPERS Chinese Giant-of recent introduction, is undoubtedly the largest and sweetest pepper ever offered.

World Beater Pepper-A cross between Ruby King and Chinese Giant, fully as early as the Ruby King, and similar in shape. As large as the Chinese Giant, but more prolific. Exceptionally mild, flesh thick, enables it to hold up for a long time.

Sweet Perfection-Productive, quality the very best; being free from pungency; and as sweet and delicious to a degree not known before.

WA TER MELONS Monte Cristo, or Kleckley Sweet-The skin is too tender to admit shipping; most desirable, however, for home market. The shape is long and it is decidedly the sweetest of all watermelons.

Irish Grey-A distinct and valuable melon; wonderfully productive. Long, thick, and uniform; color of rind yellowish grey; flesh sparkling bright red, sweet and very firm and very compast. One of the best shippers.

MUSK MELONS New Burrel Gem-With golden meat, spicy, sweet and one of the best sellers.

Hearts of Gold-A splendid, small, mid-season variety; fruit round, with tendency to heartshape; densely covered with a fine gray netting and distinctly ribbed; flesh very thick, ripening thoroughly to the rind, small seed cavity; of a rich orange color and highest quality. A fine shipping sort.

Tip Top-Grown to good size; slightly oval, sweet, juicy, yellow flesh; very popular.

Rice's Special Early Musk Melon-This is a shipping melon of the Rocky Ford order, but with a yellow flesh, and the earliest of all Rocky Ford types. In fact, one of the very earliest of the yellow fleshed Canteloupes, and is what might be termed a "comer."

PEAS Peter Pan-One of the very finest of the large podded, dwarf peas, on the order of Laxtonian, though somewhat earlier. Height $15 \mathrm{in.}$ Vine and foliage stout, heavy and dark green; pods $33 / 4$ in. long; very broad, straight and pointed, containing 6 to 8 very large, dark green peas of superb quality.

World's Record-An improved type of Gradus, being slightly earlier, more dwarf, true to type and productive. Height 2 feet. Vines moderately stout, medium green; pods medium green, 4 in. long, fairly broad, pointed and well filled with 7 to 9 very large, dark green peas of exceptional quality.

RADISHES Crimson Giant Forcing-An entirely new type, growing more than double the size of other forcing varieties without becoming pithy or hollow. The radishes run from six to seven inches in circumference, and yet remain firm and crisp. It is equally well adapted for summer and fall; matures in six to eight weeks.

Rice's Saxa-The earliest of the forcing radishes. Round, bright scarlet and with the smallest possible top. We have an excellent stock of this radish and can highly recommend it.

SPINACH

King of Demmark-A new variety of spinach. Plants form compact bushes with round thick leaves, which are rich dark green and much crumpled. It stands unusually long before bolting to seed, excellent quality. The coming Spinach.

TOMATOES Landreth's Red Rock-Earlier than the Stone, extraordinary solid, smooth as an apple, red as it is possible to be. No sort is superior in texture or flavor. A very heavy producer and an excellent shipper. Recommended especially to gardeners and planters, factories for canning, as very showy and productive. One of the finest large, red smooth tomatoes.

Joln Baer-Early, brilliant deep red color; smooth, no core; almost free from seed; delicious flavor; solid, meaty, uniform size and ripens even to stem. Perfect shipper and remarkably free from blight.

Stokes' “Bonny Best"-As early as the Earliana, enormously productive, uniform sizesplendid shape, strong vine, plenty of foliage, beautiful scarlet and a good shipper.

Marglobe-This great New Tomato introduced by the U. S. Dept. of Agriculture through the efforts of Dr. Fred J. Pritchard, of the Bureau of Plant Industry, is the last word in tomatoes. 


\title{
Select List of Vegetable Seeds
}

\author{
ASPARAGUS
}

(Eight Ounces to 100 Feet or Row)

Culture-Sow the seed in rows one foot apart in April or May and keep down all weeds. To secure strong, healthy plants, thin out the seedlings to three or four inches in the rows,

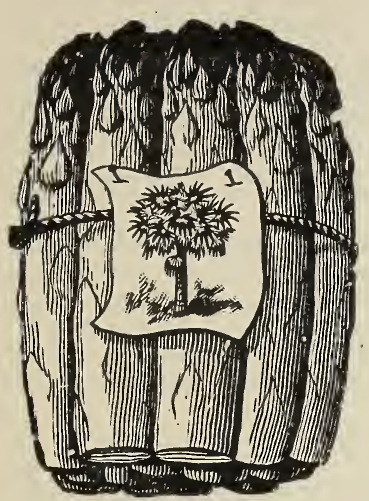
saving only the strongest. The one-year-old plants should be set out in spring in a rich, sandy loam, dug eighteen inches deep, into which has been worked plenty of well rotted manure. If a stiff clay is all that can be had, add plenty of sand and sift coal ashes to loosen it up and see that it is well underdrained. In planting for private use, set out in beds five feet wide, three rows in a bed, the outer being each one foot from the edge, and allow twelve inches in the row. Set the plants on little mounds in order to allow the rootlets to fall naturally around the sides, so they are about six inches below the surface. Select a southern exposure if possible. For market on a large scale set out 4 by 1 foot.

Every fall a good dressing of course manure should be applied after the tops have been cut, and in the spring forked in. Never cut too closely. The roots need the benefit of some foliage during the year, or they will weaken and die. A slight dressing of salt in spring is beneficial and keeps weeds down.

Palmetto-Very desirable, bright green

$\mathrm{Oz}$.

Lb.

Mary Washington-Combines strong quick growth, extreme size, uniform development of stalks, dark green colors and delicious flavor; with its greatest distinguishing quality-that of being rust-resistant. Those who grow asaparagus in quantity for marketing, will appreciate this feature $15 \mathrm{c}$

Bonvalette Giant _______ $10 \mathrm{c}$

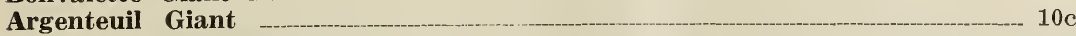

Asparagus Roots-Per dozen, 25c.

\section{BEETS}

(One Ounce Seed to 50 Feet of Row)

Paper, 5c.

Sow in April for early, for succession until last of June; about middle of May for general crop. The soil should be deep, rich and light loam, dry rather than moist. Rows should be 18 inches apart and the plants thinned out to 8 inches in the rows. If you want

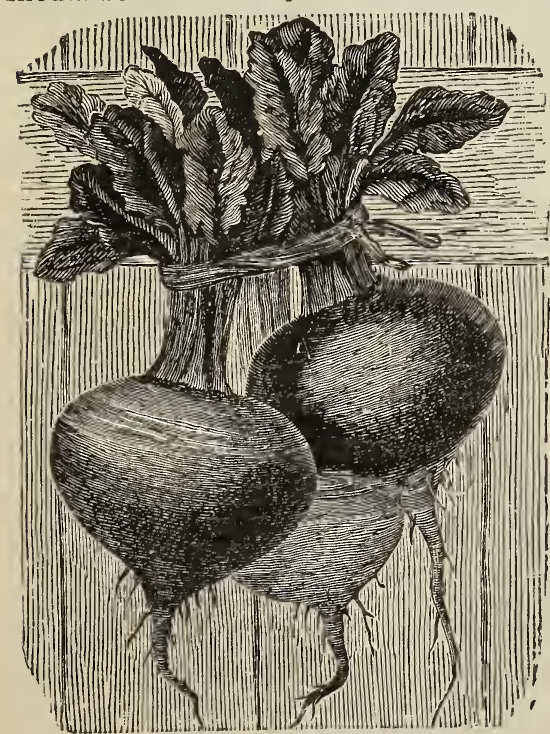
to raise sweet and tender beets, stir the soil often and kill the weeds. Wood ashes help to produce dark color.

New Model Beet--'The finest table variOz. Lb. ety of all; tender, solid and crisp flesh; of fine flavor, the color is dark blood-red; almost globular in shape $10 \mathrm{c} \$ 1.00$

Crosby's Improved Egyptian-An improvement on the Early Egyptian globe-shaped and unsurpassed eating quality

Extra-Early Eclipse-Is very early, and lasts well throughout the season. Handsome, smooth dark, globe-shaped Beet; quality very desirable; good beet for private gardens __ $10 \mathrm{c}$

Detroit Dark Red-One of the best turnip-shaped varieties. Has small upright tops; splendid shape; color of skin is dark blood red; flesh deep, bright red. Very crisp, tender and sweet; matures early and keeps in good condition for a long time_- $10 \mathrm{c}$ 
Crimson Globe-Skin smooth and form regular. The flesh is a deep purplish crimson slightly "zoned," sweet and tender. The foliage is small, of a rich bronze purple

Egyptian-Very early. For hot-bed forcing $10 \mathrm{c}$

\section{MANGEL-WURZEL}

Culture--As the mangels require a deep soil in order to grow well, plow and sub-soil if possible in autumn, at least a foot to eighteen inches, and apply plenty of rich manure. The attention of farmers to the growing of roots for feeding stock has increased rapidly, judging from the increased sales of our selected seeds. The wonderful

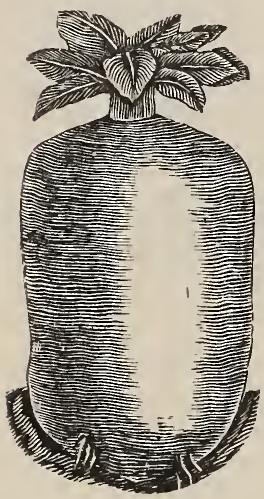
results are plainly shown in the health and general condition of the animals, and the increased yield of milk in cows.

The seed should be sown in April and May in drills two feet apart and afterwards thinned out to stand one foot apart in the rows. Keep well cultivated and you will have an abundant crop of roots for winter use. Through the winter keep them from freezing. If convenient, two sowings should be made. Anyone who keeps but one cow should plant a good patch of Mangels for winter feed. They are enormously productive under careful cultivation.

Mammoth Mangel, or Norbition Red

Oz. Lb. $10 \mathrm{c} \quad 50 \mathrm{c}$

Golden Tankard-Superior for dairy and stock feeding, and very rich in sugar $50 \mathrm{c}$

Giant Feeding Sugar-This variety is quite an improvement on the above sorts; richer in sugar; better form, more prolific, and feeders pronounce it the most satisfactory beet

Swiss Chard-The stalks and leaves are edible like spinach and asparagus, and superior to the common beet for greens. $15 \mathrm{c}$

\section{DWARF BUSH BEANS}

(Add 15c Per Quart If by Mail)

About the first of May select a warm, dry, sheltered spot, dig and manure slightly. Make drills an inch deep and two feet apart, drop beans two inches apart and cover not

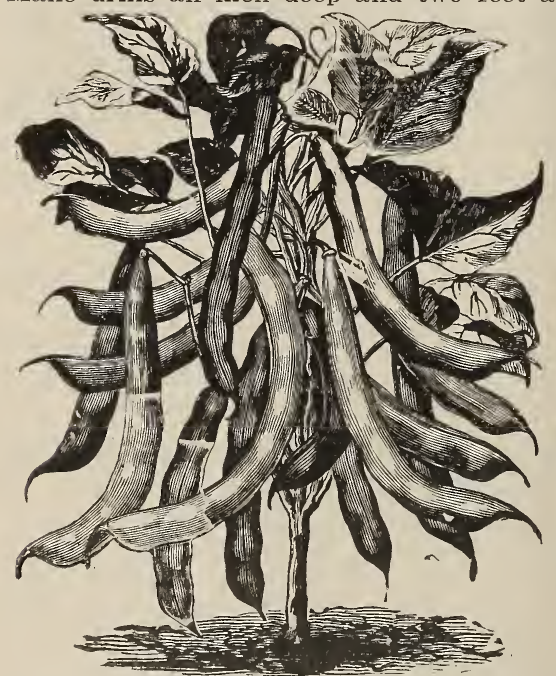
more than 'one inch deep. Keep hoed when not wet; keep the weeds killed, and plant every two weeks in succession. One quart will plant 100 feet of drill.

Bountiful-Large-sized, broad green and tender pods, stringless, very productive and fine quality $50 \mathrm{c}$

Qt. $\quad \mathrm{Pk}$

Early Red Valentine-Improved. Productive and of excellent flavor... $50 \mathrm{c}$

Early Long Six Weeks-Early and prolific - $50 \mathrm{c}$

Burpee's Stringless Green Round Pod-The coming market garden bean $50 \mathrm{c}$

Giant Stringless-Green, round_- $50 \mathrm{c}$

The Longfellow New Bush Bean-An ideal snap bean. Considering the large size of pods; it is as early as any, and no variety surpasses it in delicious flavor. The perfectly round, long straight, solid pods are its most prominent features. A good bearer $50 \mathrm{c}$

Full Measure-A very desirable, round-podded variety with pods six to seven inches long, which are solid, meaty, brittle and stringless. It is but a little later than Stringless Green Pod; is a splendid Bean for home or market use 50c 
Extra Early Refugee-It is early, enormously prolific, and. and from its earliness is it is unexcelled, being free from string, and melting tender at all stages of its growth. Price. $50 \mathrm{c}$

\section{WAX PODDED SORTS}

Pencil Pod Wax-Hardier and more prolific than the Black Wax Pods, long pencil like, tender and brittle

Golden Wax-Early and very valuable, a well known standard

Wardwell's Dwarf Kidney-Extra early; purely wax pod, long flat and remarkably free from rust

Round Pod Kidney Wax-Strong grower, stringless pods

\section{POLE BEANS}

Sow as early as the soil becomes warm and dry, from the first part of May (for all except Limas) in hills four feet apart each way. Limas should not be planted until warm weather has fairly set in. In wet and cold soil beans will rot and not come up. One quart of Limas will plant one hundred hills.

Carpinteria Pole Lima-The vine is of vigorous growth, pods very large, produce in great abundance, and closely filled with large plump beans of most excellent flavor

Qt. $\quad$ Pk.

King of the Garden-Large in pod and bean; prolific

Seibert's-Very early; large size, best quality, of easy shelling and an enormous yielder

Small Lima, or Sieva-Small, but good quality

Cut Short, or Corn Hill-An old variety, very popular, plant in corn

Case Knife-Pods long and flat; for shell and snap beans___ 60c

old Homestead-We regard this far ahead of any other green pole bean. It is early, stringless, very tender and enormously productive. The round pods hang in great clusters from the bottom

Nancy Davis Pole-A new green podded variety that is unsurpassed in quality for use as green shelled beans. In season it matures with Kentucky Wonder and vines are exceptionally vigorous and productive; pods are nearly as long as the Kentucky Wonder; nearly stringless and of excellent quality ___ $50 \mathrm{c}$

Golden Cluster-The large flat pods are of a rich golden yellow and of excellent flavor. The seeds are thick and pure white

Horticultural Pole-Excellent, either as snap or shell bean

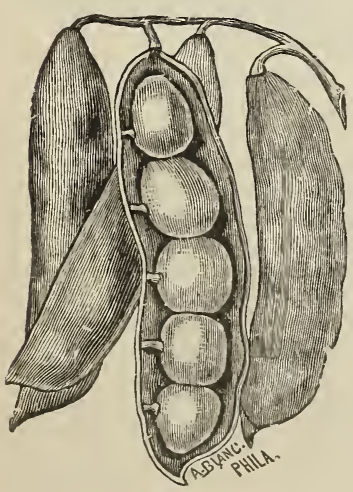

Lazy Wife-Green podded, thick fleshy, entirely stringless and of fine buttery taste

\section{BUSH LIMA}

Burpee's Improved Bush Lima-Large size_rat. 60

Fordhook's Bush Lima $60 \mathrm{c}$

Henderson's Bush Lima _- $50 \mathrm{c}$

Wood's New Bush Lima Beans-The bean is a great improvement over the Henderson Bush Lima; it is nearly double the size, of finer quality, more prolific and a stouter; stem to hold the beans from the ground

English Dwarf Beang-Plant early _._. $50 \mathrm{c}$ 


\section{SWEET CORN}

(Add 15̃c a Quart If by Mail)

Let the weather and ground become thoroughly warm and settled before planting sweet corn. If put into the ground too soon it is liable to rot. Our seed has been carefully selected, and has been tested for germination. One quart plants 150 hills-4 to 8 quarts to acre.

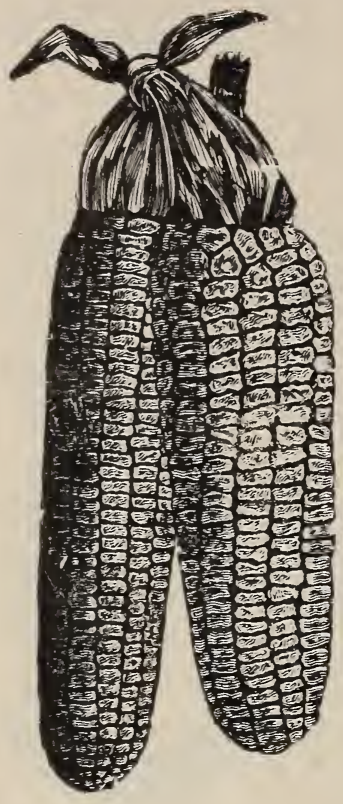

Extra Early Adams-This is not true sweet corn, but it is the earliest of all corn and a moneymaker for gardeners

Qt. Pk.

Premo-Very early and of good quality___- $35 \mathrm{c}$

Alpha-(See Page 3) -_______ $35 \mathrm{c}$

Golden Bantam-Early Yellow, very sweet and excellent quality

DeLues Golden Giant-A little later than Golden Bantam, but is larger and of good quality. Color light yellow

Charleroix-Light creamy yellow color. An excellent sort for home and market garden-- $35 \mathrm{c}$

Extra Early White Cory-Very early

Howling Mob-A few days later than Cory; but much larger, white grain, and very sweet._._. $30 \mathrm{c} \quad 2.00$

Kendall's Giant-Early and very popular sort._-_. $30 \mathrm{c} \quad 2.00$

Rice's Early Evergreen-A week earlier than Stowell's Evergreen -.. $30 \mathrm{c}$

Stowell's Improved Evergreen-For main crop, large and sweet

Country Gentlemen-Large ears and of delicious

\section{PEAS}

(Add 15c a Quart If by Mail)

Light, dry soil, not over-rich, suits the Pea. Plant as early as the ground can be worked and again every two weeks in succession throughout the season. Plant in single worked ande rows, from four to six feet apart, according to

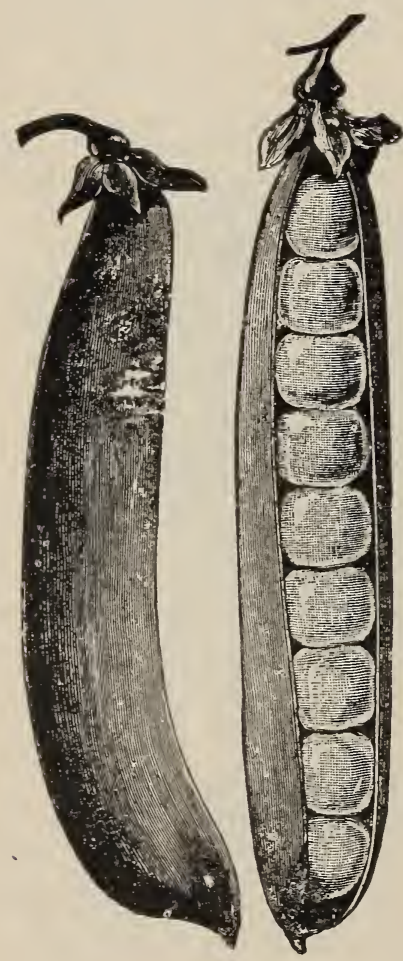
height, about an inch apart in the row and four inches deep; in the summer plant four to five inches deep. Tall sorts can be made to bear more freely by pinching in and drawing earth up to the vines.

Those marked with a * are wrinkled varieties which should not be planted until the ground is warm, otherwise they will rot and not come up.

\section{EXTRA EARLY SORTS}

Thorburn's Extra Early Market-Best strain, extra early, prolific and well filled pods; height $2 \frac{1}{2}$ feet

Qt. Pk.

laska-The best early green seeded pea; dark green pods; a good shipper; first-class in

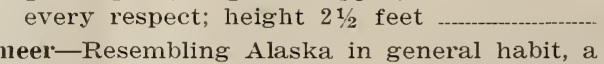
little longer vine (3 feet) and not quite so early, but with larger pods, handsomely shaped; ripens uniformly, quality excellent $50 \mathrm{c}$

Gradus-Without doubt the finest extra early pea yet introduced; it ripens almost as early as our extra early market. The pods are large and well filled with large wrinkled, deep green peas of the finest qualityheight 3 feet

Thomas Laxton-A cross between Gradus and one of the extra early sorts. Ripens within a day or two of the earliest round varieties, very productive. The pods are large and contain 7 or 8 large, wrinkled peas of the finest. flavor; height 3 feet 
Mammoth Podded Extra Early-On the order of Rice's Extra Early, but pods Qt. one-fourth larger. Matures practically with Extra Early and Alaska and is much more productive; seed large, smooth and white. Vine and foliage robust, heavy and medium green. Height 3 feet. Pods light green, 4 in. long, round, broad, saddle-backed and square ended, containing 7 extra large light green peas. A very productive and extra fine sort, bound to take flrst place as a leading market gardener's fir'st early pea

\section{DWARF-EARLY}

*American Wonder-Vigorous, productive, most desirable early pea for private gardens; height 12 inches

Qt. $\mathrm{Pk}$.

Nott's Excelsior-Pods one-third longer than Wonder; height 12 inches -...-50 $50 \mathrm{c}$

*Sutton Excelsior-Produces broad pods, filled with large peas; of finest flavor; in great abundance; height 12 inches

eter Pan-One of the very finest of the large podded, dwarf peas, on the order of Laxtonian, though somewhat earlier. Height 15 in. Vine and foliage stout, heavy and dark green; pods $3 \frac{3}{4}$ in. long, very broad, straight and pointed, containing 6 to 8 very large, dark green peas of superb quality

* Little Marvel-A new early wrinkled pea, as early as American Wonder; very prolific and sweet. It grows about 15 inches, produces a heavy crop of deep green pods which are frequently borne in pairs ___ $50 \mathrm{c}$

\section{EARLY AND MEDIUM}

*Horseford's Market Garden-A favorite for market gradeners and home use; pods are larger and well filled; height $2 \frac{1}{2}$ feet

\section{GENERAL AND LATE VARIETIES}

Daisy or Dwarf Telephone-Productive, large peas and pods; height $1 \frac{1}{2} \mathrm{ft}$..... $50 \mathrm{c}$

Telephone-Gardeners prefer this pea to any other on account of its sterling qualities, producing an abundance of large pods filled with enormous tender peas; height 4 feet

\section{CABBAGE}

(Sow half an ounce in hot bed 6 by 4 feet; four ounces to one acre) Package 5c. Sow early sorts in hot beds during February and March and transplant middle of April.

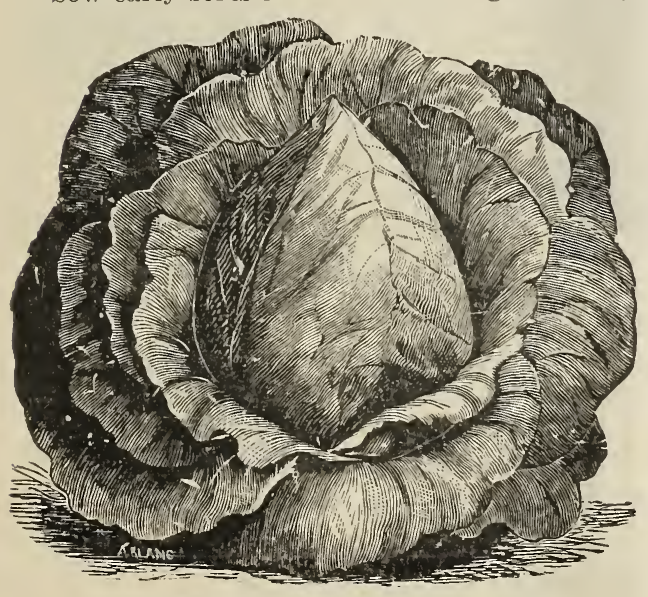

Jersey Wakefield Cabbage Sow later crop in April and May. They should be sown in shallow drills, four to six inches apart. When the plants are six inches high, transplant into rich manured ground, the early kinds two feet apart and the later kinds three feet. The ground must be deep-loosened and worked thoroughly to grow large and good heads. Hoe often to kill weeds and draw some earth upon the stems. If troubled by the cabbage flea, sprinkle the plants with Slug Shot, soot, wood ashes, lime or Scotch Snuff. Either of the above will drive them away. One ounce of salt petre dissolved in twelve quarts of water will destroy the green worm. Set plants deep in the ground.

Our Cabbage Seed is of the best strains. There is no better stock grown -and should not be confounded with cheap, imported stock.

Early Jersey Wakefield-Finest American, select stock, grown almost to the exclusion of all others by market gardeners

Oz. $1 / 4 \mathrm{Lb}$.

Charleston Wakefield-Very large and finest strain of the above..

New Early Cabbage, Copenhagen Market-Undoubtedly the finest, large, round, headed early cabbage. The heads average about ten pounds each in weight, are very solid, and fine quality. It matures as early as Charleston Wakefield and will give a heavier yield per acre than that well known variety. 'The plant is short-stemmed, the leaves light green, rather small, and always tightly folded. The plants, therefore, can be set closer together than is usual with varieties of smaller size $25 \mathrm{c} \quad 75 \mathrm{c}$

The Golden Acre-A new sort, about one week earlier than the Copenhagen market, which type it resembles, but smaller heads, therefore can be planted closer in the rows. 


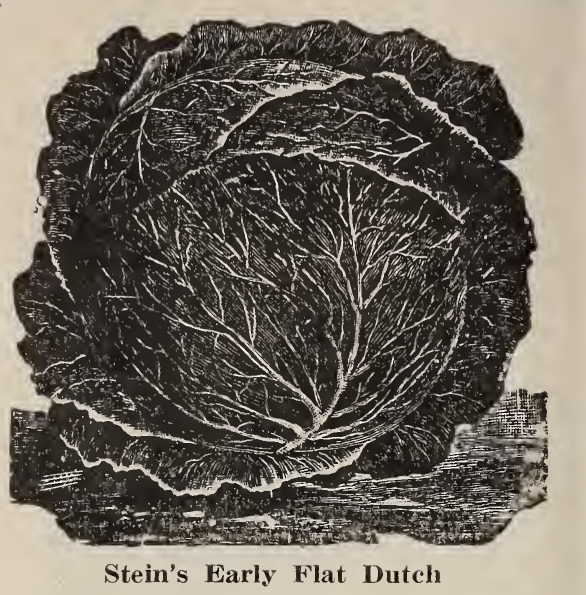

Stein's Early Flat Dutch-Earliest flatheaded cabbage; succeeds the Jersey Wakefield. A remarkably fine strain; a sure solid header: weighing ten to twelve pounds eachvery best quality and most valuable for market; has a most excellent reputation

Improved Early Summer or Excelsior -The finest, best second early...... 25c

Selected All Season, or Succession Cabbage-One of the best second early or late, growing to a large size quickly, and sure to head …_... 25c

\section{LATE}

Danish Ball Head-Round solid heads best cabbage to sell in spring $30 \mathrm{c}$

Large Flat Dutch-American _- $25 \mathrm{c}$ Large Flat Drumhead-American _..._.. 25c Improved Drumhead Savoy - $30 \mathrm{c}$

St. Louis Market-This is the finest and best late cabbage ever put on the market. Stands longer on the field after maturing without bursting. An excellent keeper and shipper

\section{CAULIFLOWER}

Culture--This is the same as for cabbage, except that extra manure and plenty of water will pay upon this. If the soil be dry, water frequently; and if the plant could have a heavy

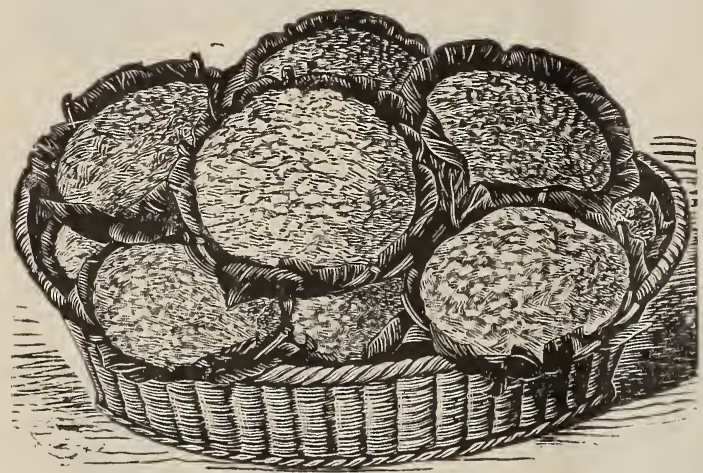
mulch of hay or straw, it would not suffer from drouth. The early kinds should be strong enough to plant out not later than the middle of April; the late kind may be planted out the same time as for cabbage. To destroy the cauliflower maggot, it is recommended, to take one ounce of sulphuret of potassium and dissolve in one gallon of water. Heat the liquid to about 100 degrees, take a large spoon or something that will hold a 100th part of a gallon, and pour the liquid against the stock of the plant just above the ground.

Gilt Edge Cauliflower.

Henderson Early Snow Ball-One of the best for forcing or open ground, sure header.

Thornburn's Gilt Edge-Large, heavy sort, undoubtedly the best and surest of all sorts now in cultivation.

The above two kinds are the best and most successful for this climate.

Price of each sort-20c per paper; $\$ 3.00$ per oz.

\section{SLUG SHOT IS SURE DEATH TO GREEN WORMS ON CABBAGE AND CAULIFLOWER}

Use the Lowell Dust Blow Sprayer

Chinese Celery Cabbage of Pe-Tsai-It resembles Cos lettuce, inner leaves blanch creamy white, distinct flavor, mild and pleasant. It is served as a salad like lettuce, or cooked like asparagus. Oz. $30 \mathrm{c}$

\section{CARROTS}

(One Ounce to 100 Feet of Row) Package, 5c.

Sow as early as the ground can be worked, or, for late crops, until latter part of July. For main crop, sow from middle of May to the first of July. Thin out early crop to five inches in the row, main crop six to seven inches apart. Hoe often and deeply between rows. Soil light, sandy loam, richly manured and deeply dug, and a good supply of wood ashes. Sow at the rate of two pounds to the acre. 


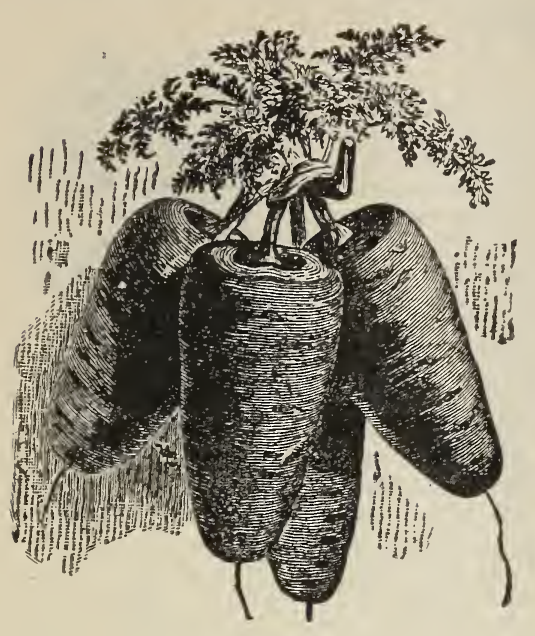

Deep culture secures quick growth and clean root, while otherwise the roots become wormy and ill-shaped.

Or. $1 / 4 \mathrm{Lb}$.

Guerande or Oxheart-Half long stump-rooted; orange color and of excellent flavor when young... 15c $40 \mathrm{c}$

Early Scarlet Horn--Very thick roots $15 \mathrm{c} \quad 40 \mathrm{c}$

Chantenay-Half long stump rooted; fine for garden and field $15 \mathrm{c} \quad 40 \mathrm{c}$

Half Long Pointed-Much used for bunching when young ___ $15 \mathrm{c} \quad 40 \mathrm{c}$

Half-Long Danvers--Thick, good quality, exceedingly productive ...... $15 \mathrm{c}$

Early Half Long Nantes-Excellent stump-rooted variety and of superior quality --orang-For late planting and best for stock $15 \mathrm{c}$

\section{CELERY}

(One Ounce to 100 Feet of Row) Package, 5c.

Sow seeds in hot-bed or in a box in the house, or in the open ground as soon as it can be worked. If seeds are sown in beds, care should be taken to keep the surface moist so that the ground does not bake, otherwise the seed will not come up.

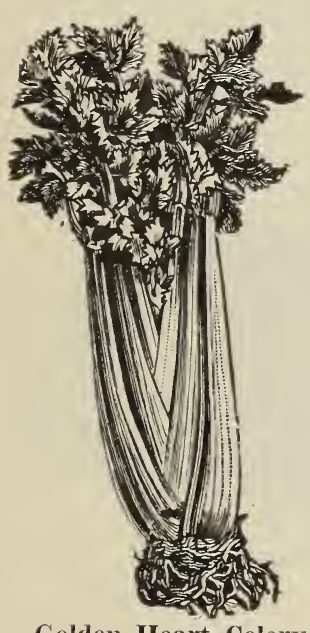

Golden Heart Celery

When the plants are two to four inches high, make trenches a foot deep and four to five feet apart.

Enrich thoroughly the bottom of the trenches and transplant six to eight inches in the rows, and as the plants grow, haul the earth about them to blanch their stems. Care should be taken not to let the earth get in the heart of the plant. Never trench while wet from dew, or other causes, otherwise it has a tendency to rot and rust badly. Our celery seeds are of all American growth.

White Plume-Best early; very extensively grown.-.- $25 \mathrm{c}{ }^{1 / 4} \mathrm{Lb}$. Golden Self Bleaching-A fine golden solid yellow variety $40 \mathrm{c}$

Giant Golden Heart-A vigorous grower; best for market garden ___ 25c 1.00

Giant Pascal-Large and later than above and very popular $25 \mathrm{c}$ $85 \mathrm{c}$

Winter Queen-It is undoubtedly the best late keeper; solid and crisp; blanches well $30 \mathrm{c}$

\section{CORN SALAD}

Package, 5c.

Sow in drills 6 inches apart; cover early in spring in drills a quarter of an inch deep and 6 inches apart. If dry weather, tread in the seeds lightly. Keep down the weeds with hoe. Just before winter sets in, cover thinly with clean straw.

\section{CRESS}

Sow in drills 6 inches apart; cover lightly. 


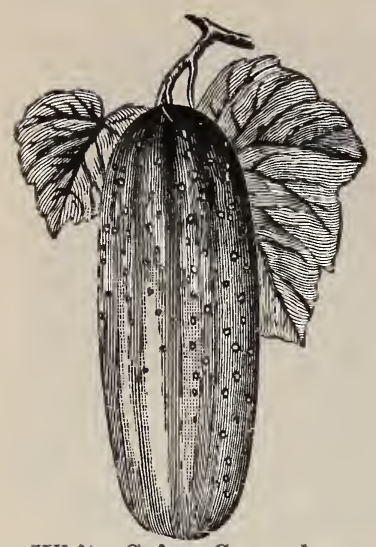

White Spine Cucumbers

\section{CUCUMBERS}

In February and March plant seeds in hot-beds and when night frosts are gone, plant out in rich and new dug ground in hills and ridges from 4 to 5 feet apart. Stop the leading shoots continually as the fruit shows; or plant the seeds in open ground as soon as the weather becomes settled and warm. Use a shovelful of warm manure to each hill, and cover with an inch or two of earth; scatter 8 to 10 seeds in a hill, cover half an inch and press it down. Hoe often, and when out of danger from insects, thin the plants to four in a hill. For pickles plant from June to July. One pound to the acre.

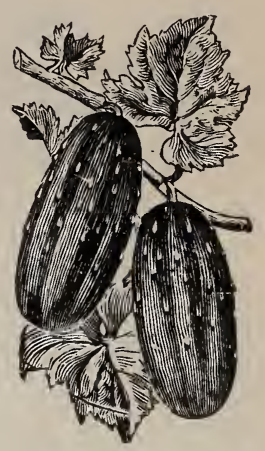

Cluster Cucumber

Fordhook Famous-Long, straight and well formed; vigorous grower, very Oz. productive, does not turn yellow

Rice's Early Fortune-See page 4 - 15c

Early White Spine-Best for early market, also good for pickles

Chicago or Westerfield-One of the best pickling varieties

Long Green Giant Perra-Best for table. An old standard sort ___ 15c

The New Cumberland-Best pickling cucumber known______ $15 \mathrm{c}$

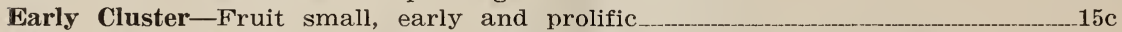

Kirby Stay Green-Early, seven to eight inches long, cylindrical in shape, color dark green from stem to blossom end, which is retained longer than any other variety. Vigorous grower, enormous yielder, quality unsurpassed _- 20c

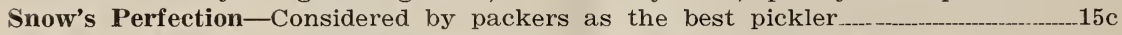

Davis' Perfect-Very early, long and slim; keeps dark and glossy green a long time. It is very tender, brittle and of good flavor $15 \mathrm{c}$

Japanese Climbing-Produces long, evenly shaped crisp, tender fruit in abundance. The vine has a tendency to fasten itself to any object over which it may grow. In small gardens where space is limited, it may be planted and trained on trellisses to good advantage $20 \mathrm{c}$

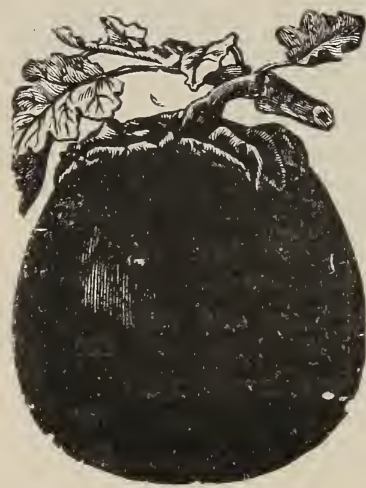

N. Y. Improved Egg Plant

\section{EGG PLANT}

(One Ounce to 1,000 Plants). Package 5c.

Culture-Sow in well heated hot-beds, very early in spring and transplant when 2 inches high into a second bed or into small pots. If this is not done, thin to 4 inches apart. Do not plant out until it becomes perfectly and warm. Cool nights or wet weather will check them. Keep some back in frames for second planting, in case of weather changing unexepectedly. Keep plants watered for a few days, if the sun is hot when put out. Set out plants three feet by two.

Improved New York Purple-The best; large oval in shape and of deep rurple color; grown very much more extensively than any other sorts both for priveate use and market

New Black Beauty-As large as above and ten days earlier; very rich and purplish black color..

\section{ENDIVE}

\section{Package, 5c.}

(One Ounce to 150 Foot Row)

From May to July sow thin and cover slightly. When up, thin out to 8 inches apart, and give good watering afterwards when dry. When leaves are eight inches long, blanch them by gathering the leaves in the hand and tieing them together near the top, with yarn or twine; this must be done when quite dry or they will rot. Excluding light will blanch them.

Green Curled-Very hardy, best adapted for winter use

White Curled-A splendid early sort

Broad-Leaved (Escarolle)-A sweet variety for fall A

De Ruffec-Large, green curled broad ribs, fine for fall and winter, the best

and most exquisite extant 


\section{KALE OR BORECOLE}

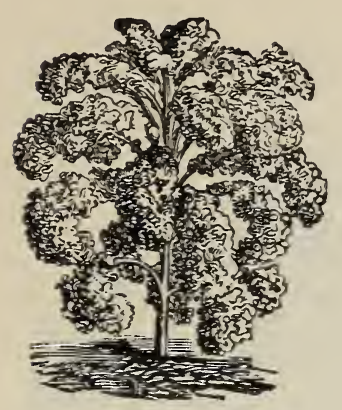

Curled Scotch Kale

Package, 5̌c.

Sow one ounce to 100 feet in the row, and four pounds to the acre. Kale requires same treatment as cabbage. It gets most delicious after being touched by a frost. The more hardier sorts sown in fall for spring use, should be covered with straw through the winter.

Dwarf Green Scotch Curled-This is not as hardy as some, but more curled, sown in spring $10 \mathrm{c}$

Improved Siberian or Dwarf German Green-Best and hardiest for fall sowing

Tall Green Scotch Curled $20 \mathrm{c}$

\section{KOHL-RABI}

Package, 5̃.

(One Ounce to 100 Foot Row)

May be sown April to July, and the plants afterwards treated the same as cabbage; only be careful not to hoe too much soil around the stem. Plant out in rows ten inches apart.

It is in best condition for use before it becomes fully grown, even while quite small. Delicious flavor like cauliflower.

\section{Early Vienna-}

Flesh white and tender Oz. $30 \mathrm{c}$

\section{LETTUCE}

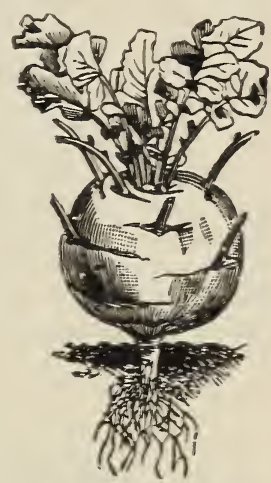

Vienna Kohl-Rabi

Package, 5̃c.

(One Ounce Will Produce About 3,000 Plants)

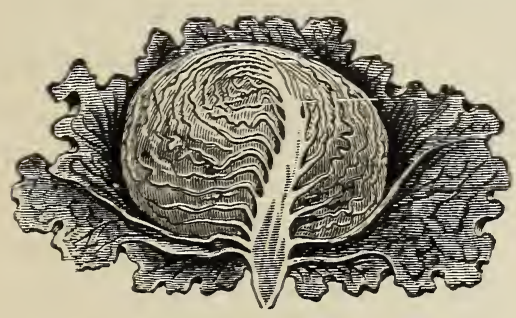

Curled Lettuce

Sow in frames in February and March and in the open ground as soon as the ground can be worked, and thin out or transplant in rows nine inches to a foot apart. Sow every three weeks in succession during the spring and summer. In September and October sow the winter varieties in hot beds. Lettuce requires good ground and moisture in abundance; hoe carefully and keep weeds down. Often lettuce under glass is affected by green flies-three or four applications of Aphis Punk smoke will kill them, especially if the plants are not too large. If under hot-bed culture, sow tobacco dust with the seed.

Lettuce seed, particularly the Grand Rapids, is exceedingly sensitive to unfavorable conditions for germination, especially when sown in the house, and gardeners often fail to get satisfactory results from the seed, which is of good vitality.

In order to get good germination the seed should be sown in light soil and great care taken not to cover too deeply-1/4 inch of soil being abundant covering. After planting, care should be taken that the soil is not packed and crusted over the seed by too heavy watering.

Big Boston-Especially adapted for greenhouse culture and valuable for market gardeners

Oz. $1 / 4 \mathrm{Lb}$

May King-New, extra large round, solid head, green outside, with clear, yellow heart, of fine flavor and splendid forcing

Wonderful-Large white head resembling cabbage, very solid, rich and tender $20 \mathrm{c} 75 \mathrm{c}$ Hanson-A standard; heads very large, solid, tender and crisp___ $15 \mathrm{c} 60 \mathrm{c}$ 


\section{LETTUCE-Continued}

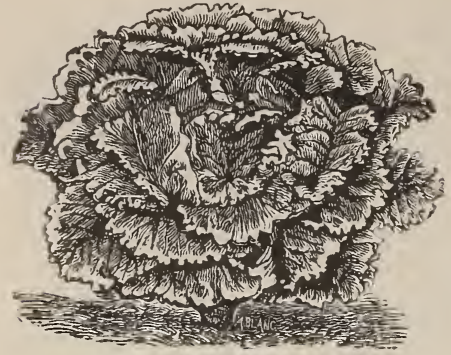

Curled Simpson Lettuce

Simpson-Black seed for forcing and outdoors

(trand Rapids--This grand forcing variety stands more neglect in the way of watering and ventilating than the black-seeded Simpson: It is of handsome appearance, a strong grower and will keep from wilting longer than others. Its upright habits admits of very close planting _____ $15 \mathrm{c}$

Iceberg-Large, solid, curled heads, yellow heart, crisp and tender

Black Seeded Butter-Large, yellow heads _- 20c $75 \mathrm{c}$ Brown Head and Curled $20 \mathrm{c}$

\section{LEEK}

(Two Ounces to 100 Feet in Row)

Sow very early in the spring, in drills 6 inches apart and $1 / 2$ inch deep; thin out to one inch apart. When seven inches high, plant out in rows eight inches apart and as deep as possible, so as not to cover the young center leaves. Water thoroughly, if dry weather when planted out; draw earth up to them as they grow; requires very rich soil.

Large Rouen-A very large growing sort

Oz. $40 \mathrm{c}$

Large Musselburg-For winter use

Oz. $40 \mathrm{c}$

\section{MUSK-MELON}

(One Ounce to Seventy Hills, Two Pounds for An Acre) Package 5c.

Plant late in spring, in hills five feet apart; ten seeds in a hill; draw soil up around the stems and top their points to make-them branch when they begin to run.

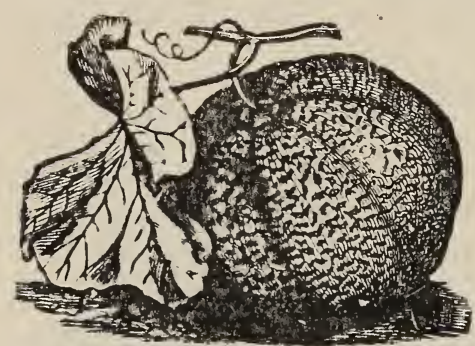

Warm, light, but rich sandy soil suits them best. Dust a little soot or recently burned wood ashes on the plants when up.

Oz. $1 / 4 \mathrm{Lb}$.

New Burrell Gem-With Golden meat, spicy, sweet, and one of the best sellers

$40 \mathrm{c}$

Gold-Lined Netted Rock-Delicious, flesh thick, fine grained and sweet; color green, with a gold margin next the seed cavity; slightly oval and heavily netted

Hearts of Gold-A splendid, small, mid-season variety; fruit round, with tendency to heart-shape; densely covered with a fine gray netting and distinctly ribbed; flesh very thick, ripening thoroughly to the rind; small seed cavity; of a rich orange color and highest quality. A fine shipping sort ___

$40 \mathrm{c}$

Defender-New or regular even size and finely netted; about seven inches in

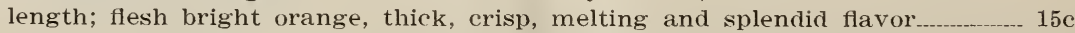

Selected Rocky Ford-This is a popular green fleshed, medium sized melon of delicious flavor

Salmon Tinted Pollock No. 10-25-Rust resistant, meat very fine texture, deep and firm. Color of meat green one-half the depth from the rind, and remaining one-half rich salmon, giving an attractive appearance. Netting closely laced and interlaced, uniform in size, making it a good shipper._. $15 \mathrm{c}$

Tip Top-Grown to good size, slightly oval; sweet, juicy, yellow flesh _.__ 15c

Hackensack-Extra early, large round, green flesh, productive and of good quality

Emerald Gem-Small, extra early, smooth ribbed, dark green skin, orange flesh, quality first-class _.___ $15 \mathrm{c}$

Osage Selected-Large, green skin, cocoanut shaped, salmon flesh, very fine....... 15c

Banana-Long, slender, salmon flesh; white and light green $40 \mathrm{c}$ $40 \mathrm{e}$ $40 \mathrm{c}$ $40 \mathrm{c}$ 


\section{WATER MELONS}

Package, ãc.

Culture-Form large and well-drained hills of rich earth, avoiding the use of fresh manure in such a way as to cause the plant to dry out under the hot sun. On this hill plant the seed as soon as the ground is warm and dry, and carefully protect the young plants from insects, and hasten their growth by the use of liquid manure.

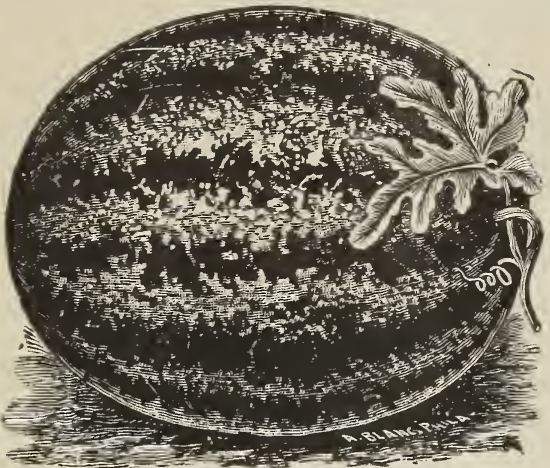

Kolb's Gem Water Melon

Fordhook Early-Very early, me $\mathrm{Oz}$ dium size, short and blocky, dark green, thin rind, flesh bright red and sweet _... 15c

Halbert Honey-Skin dark green; flesh crimson; very sweet. Fine for planting in the North ..... $10 \mathrm{c}$ $75 \mathrm{c}$

Monte Cristo-Exceedingly sweet and fine flavored; dark green skin; thin rind; flesh scarlet, solid and firm; long … $10 \mathrm{c}$

Florida Favorite-Improved Rattlesnake, superior strain 15c

Tom Watson-Extra long melon, uniform in shape, and quality; flesh luscious crimson; sweet as honey; hest size and shipper $10 \mathrm{c}$

Sweet Heart-Very large, light green skin, fine quality $10 \mathrm{c}$

Alabama Sweet-Large and long; firm, dark green, striped rind; flesh bright red; delicious flavor, and good shipper.

Irish Grey-A high quality, good shipping, new watermelon from the South; it is of the popular long shape and has a distinct color-a mottled greenish grey. The rind is thin and very tough. As a shipper it is equal to the Tom Watson. Quality is the vely highest; sweet, flesh red and crisp (free from stringiness). The plants are vigorous and bear much longer than other crops, producing fruits when other varieties have died out

Kleckley Sweets-Improved Monte Cristo, Colorado grown $15 \mathrm{c}$

\section{SPECIAI, PRICES ON LARGE QUANTITIES}

\section{MUSTARD}

(One Ounce to 50 Foot Row). Package 5̃.

Sow thickly durng April and early May in shallow drills.

Oz.

L.b.

White English $10 \mathrm{c}$

\section{ONION}

(Two Ounces to 100 Feet of Row; 4 Pounds to the Acre)

First-class Onion Seed can never be low in price when counting labor and expense of producing good and reliable seed.

Land of a sandy loam, with light mixture of clay, is easyto work, and produces good crops; particularly if it has been worked two years previously in hoed crops kept free from weeds. Have the land heavily manured and plowed the fall previous. In the spring as early as the ground can be worked, give it a thorough dragging, after which rake. Stretch the lines perfectly straight in marking, and sow your seed.

Procure good seed, no matter what its cost is, for without it all your labor will be lost. It requires three to four pounds of seed to the acre. If large onions are wanted sow thin.

After the seed is up it is of great importance to keep the weeds down; if that is not done at an early stage when weeds appear, the crop will surely be a failure.

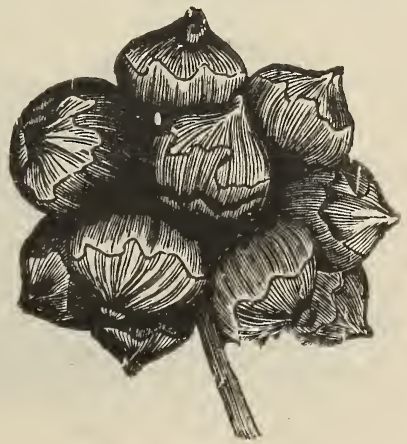




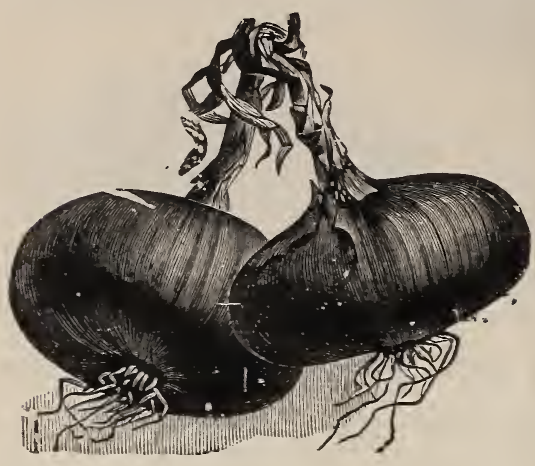

\section{ONION SETS}

Red Bottom Onion Sets, raised from seed. Yellow Bottom Onion Sets, raised from seed. White Bottom Onion Sets, raised from seed. Red Top Onions.

\author{
Price on Application.
}

ALL OUR ONION SEED IS OF LAST IEAR'S GROWTH AND SHOULD NOT BE CONFOUNDED WITH CHEAP AND OLD SEED.

Large White Globe-Southport strain

Oz. $1 / 4$ Lb. Lb.

Large White Portugal-Mild and delicious flavor. It is the most exten-

sively grown for growing sets of fine quality, and salable $\quad 30 \mathrm{c} \quad 90 \mathrm{c} \quad 3.25$

Large Red Wethersfield-A good keeper $\quad 25 \mathrm{c} \quad 60 \mathrm{c} \quad 2.25$

Large Red Globe, Southport-Southport strain, good keeper $\quad 25 \mathrm{c} \quad 60 \mathrm{c} \quad 2.25$

Large Yellow Globe, Southport-Extra fine strain _-_ 25c $\quad 60 \mathrm{c} \quad 2.25$

Large Yellow Globe, or Prize Taker-Light yellow, of enormous size _r_ 25c $\quad 60 \mathrm{c} \quad 2.25$

\section{SPECIAL PRICES ON LARGER QUANTITIES}

The sowing and growing of this valuable and renumerative crop used to be an extreme$l y \cdot$ tedious and laborious business, but since the introduction of the Hand Drills and Cultivators-of which we have the largest and

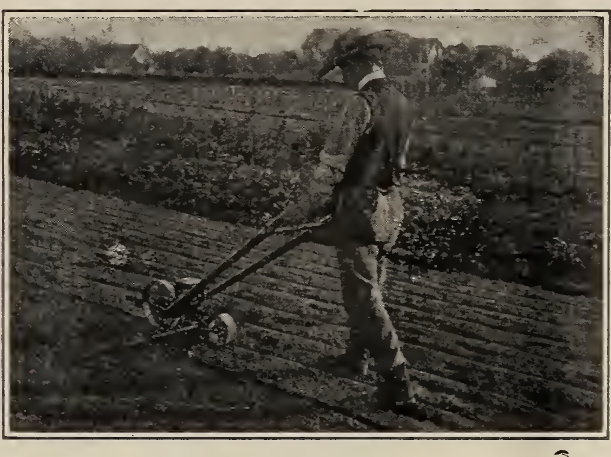
most improved patterns-it is comparatively easy to raise a large crop at a moderate expense.

\section{New Method of Raising Onions}

Of late, Eastern onion growers em. ployed a new way of raising large crops of onions with success. This mode is to sow the seed carefully from March 1st to 15 th, in warm beds, in drills one inch deep and three inches between the rows. In about four weeks the plants will be about the size of a lead pencil and ready to set out in well prepared soil, in straight lines from three to four inches apart and twelve inches between the rows. Have the tops and roots somewhat shortened by cutting so you get a stiff plant. In this way plants are easier to handle, and stand more erect in the row.

\section{OKRA}

Package, 5c.

(One Ounce 40 Feet Row)

Sow late in spring after the ground has become warm, in drills three feet apart in rich manured land. Thin out from six to nine inches.

Dwarf White-Early and productive

Oz. $10 \mathrm{c}$

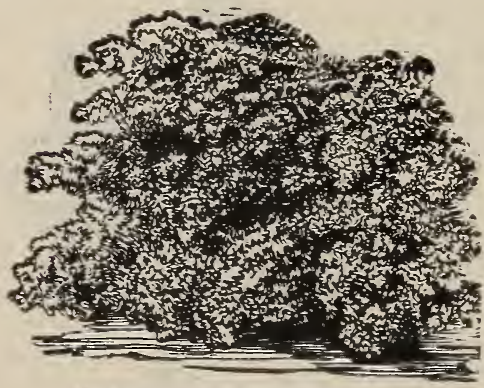

Moss Curled Pareley.

\section{PARSLEY \\ Package, 5c.}

(One Ounce to 150 Feet Row)

Soak the seed a few hours in warm water. Sow in spring in drills one foot apart. To preserve in winter, transplant in a light cellar or cold frame.

Moss Curled

Oz. $1 / 4 \mathrm{Lb}$.

Plain Leaved

$15 \mathrm{c} \quad 50 \mathrm{c}$

$15 \mathrm{c} \quad 50 \mathrm{c}$ 


\section{PARSNIPS}

Paclkage, 5c.

(Five or Six Pounds to the Acre)

Sow during spring in drills one inch deep, and when three inches high, thin out from six to eight inches apart in the row; hoe often; soil should be rich and deep. May be left in the ground over winter and dug in the spring as required. Even fresh seed is sometimes hard to germinate. In dry weather have the soil well firmed after sowing.

Hollow Crown-Best for general use_Oz., 10c; 1/4 Lb., 30c; Lb., $\$ 1.00$

\section{PEPPER}

Package, 5c.

(One Ounce Will Produce About 1500 Plants)

Sow in hot-beds in March, or in open ground in a seed-bed the latter part of April in light, warm ground; when three inches high, transplant to 18 inches apart each way; hoe frequently. Seed is slow to germinate, and requires a good warm hot-bed. Pepper plants can also be grown in small pots.

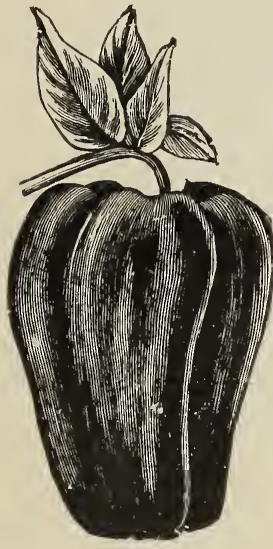

Ruby King Pepper

Sweet Perfection-Very productive quality, the very best, being free from pungency and sweet and delicious to a degree not known before

New Chinese Giant-Of recent introduction, is undoubtedly the largest and sweetest pepper ever offered.

Giant Crimson-Early in maturing, plant growing extremely large size, claimed to be larger than Chinese Giant. Color deep green when young, and deep crimson when matured; flesh thick, sweet and mild.

Ruby King-Mild and one of the best, 4 to 6 inches long and 3 to 4 inches thick $40 \mathrm{c}$

Cayenne-The variety of Commerce; long narrow pods; pungent

World Beater Pepper-A cross between Ruby King and Chinese Giant, fully as early as the Ruby King, and similar in shape. As large as the Chinese Giant, but more prolific. Exceptionally mild, flesh thick, enables it to hold up for a long time

Neapolitan-Very early, large and mild

\section{PUMPKIN}

Kentucky Field-Large, round, salmon color, especially for stock feeding; harảy and prolific

Connecticut Field-Grown in corn-fields for stock

Large Cheese-Flat; one of the best varieties for family use$40 \mathrm{c}$

Japanese Pie-Similar to the Cushaw, fruit matures early; meaty and of first quality; seed is curiously marked.

Small Sugar-A small, sweet, delicious variety of deep orange color; prized highly for making pies

Quaker Pie-Pear shaped, rich flavor, and good keeper

Tennessee Sweet Potato-Bell-shaped; thick, white flesh; fine for pies

Mammoth King-Grows enormous size $10 \mathrm{c} \mathrm{Oz}$

\section{RADISH}

Package, 5c.

(One Ounce to 100 Feet Drill)

Sow in sheltered spot as early as the ground can be worked, and every two weeks until summer; then commence planting the summer varieties. The winter sorts should be sown in August. A light rich soil suits best. It should be borne in mind that Radishes must have plenty of room, otherwise they will be tough and wormy. Slightly sprinkling of. salt is beneficial. 


\section{RADISH-Continued}

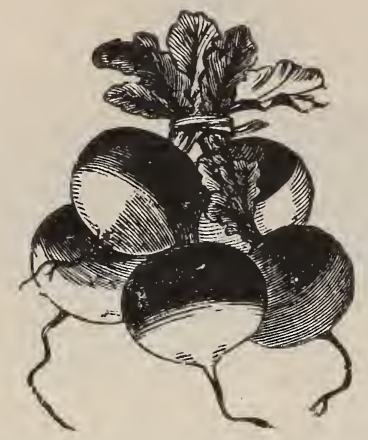

Cooper's Sparkler-Carmine, scarlet half white Oz. Lb. tipped; fine for forcing and open ground

Deep Searlet, Turnip Forcing-Short top, crisp and handsome

Non-Plus Ultra-Extra early, scarlet forcing-.. $10 \mathrm{c} \quad 1.00$ The above kinds mature in about 25 days.

Scarlet Turnip-Very early $10 c$

Scarlet Turnip, White Tip-Very early, for hotbeds and outdoors 10c

Vick's Scarlet Globe-For forcing and best for open ground $10 \mathrm{c}$

Crimson Giant Forcing-An entirely new type, growing more than double the size of other forcing varieties without becoming pithy or hollow. The radishes run from six to seven inches in circumference, and yet remain firm and crisp. Is equally well adapted for forcing or outdoor cultivation

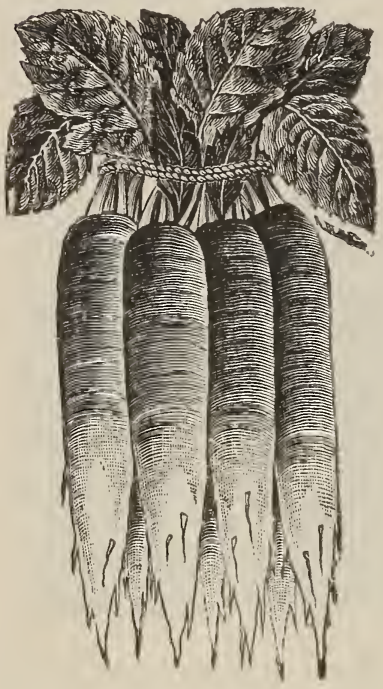

Rice's Saxa-The earliest of the forcing radishes. Round, bright scarlet and with the smallest possible top. We have an excellent stock of this radish and can highly recommend it

Iong, Bright Scarlet

Icicle-The name is given in allusion to the shape and the transparent whiteness of the root. The leaves are short. It is the first long, white forcing radish yet introduced.... 10c

Golden Globe-Popular Market Gardeners' sort

Chartier-Long, scarlet, white tipped …. 10c $\quad .85$

White Long Strassberg $10 \mathrm{c} \quad .85$

Large, White Round Stuttgart $10 \mathrm{c} \quad 1.00$

China Rose-For fall and winter $10 \mathrm{c} \quad 1.00$

California Manmoth - Very large winter variety $10 \mathrm{c} \quad 1.00$

Black Spanish, Long _... 10 1.00

\section{SALSIFY OR VEGETABLE OYSTER}

(One Ounce 50 Feet Row)

When cooked forms a substitute for oysters, as the flavor is very similar.

Sow early in spring, drills one foot apart, one inch deep, and thin out to 4 inches in the row; keep clean and cultivate the same as parsnips. To leave them in the ground during the winter will not injure them.

Mammoth Sandwich Island-A large and superior variety.

Oz. $1 / 4 \mathrm{Lb}$. $15 \mathrm{c} \quad 40 \mathrm{c}$

\section{SPINACH}

Package, 5c.

(12 Lbs, to An Acre)

Sow half an inch deep and a foot between the rows; thin out to eight inches; as soon as frost is out of ground; hoe frequently to prevent the plants from running to seed. For winter crop, sow latter part of August or September. Lay straw between the rows at approach of winter, and very thinly over the leaves. 


\title{
SPINACH-Continued
}

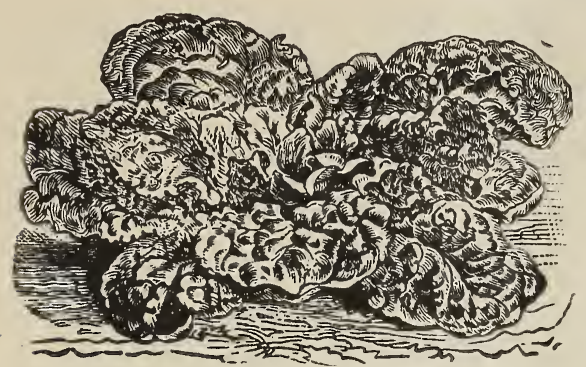

Thick Leaf--Generally preferred for

spring sowing --oved-A pro-
Bhoomsdale, Savoy-Leaved-A

Oz. Lb. ductive variety, quite hardy

Long Standing-The longest standing before running to seed, and consequently one of the best varieties

$50 \mathrm{c}$ Prickley 3 to 5 lbs., $40 \mathrm{c}$ per $1 \mathrm{~b}$. 10 lbs., $30 \mathrm{c}$ per $\mathrm{lb}$.

King of Denmark-A new variety of spinach. Plants form compact bushes with round thick leaves, which are dark green and much crumpled. It stands unusually long before bolting to seed; excellent quality. The coming Spinach.. Lb. $60 \mathrm{c}$

\section{SQUASH}

Plant in hills in the same manner and at the same time as melons; the bush four feet and the running kind 6 to 8 feet apart.

Squash cannot be planted with any degree of safety in the middle or northern states before the middle of May, as they are extremely tender and highly sensitive to the action of bad weather.

White Bush, or Scallop Summer

Oz. Lb. $15 \mathrm{c} \$ 1.25$

Improved Large Summer Crookneck $15 \mathrm{c} \quad 1.25$

Delicious-Green skin; orange flesh, fine-grained, sweet and dry__ $15 \mathrm{c} \quad 1.50$

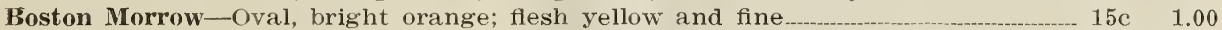

Warted Hubbard-A general favorite for late use, and of superior quality $-15 \mathrm{c} \quad 1.50$

Sibley's or Pike's Peak-One of the finest winter varieties; thick, bright orange flesh

Ford Hook-Excellent keeper through the winter, of finest quality and good for

all purposes ... $15 \mathrm{c}$

\section{TOMATO}

(One Ounce Will Produce About 2500 Plants)

\author{
1/2-Ounce in Hot-Bed $6 \times 4$ Feet
}

Sow in hot-beds in February and March and transplant in open ground when the weather becomes warm and settled, or sow in open ground in May, and transplant when plants are six inches high, four feet distant from each other; soil should be made light and ricl. By transplanting plants in pots, fruit may be had several weeks earlier, and pinching off the small tips will hasten the ripening considerably. The plants, before setting out, ought to be hardened until the stalk gets to be red. Should the plants be long and slim, put them in slanting. Old manure should be used in the soil.

Our Tomato Seeds are unequalled for their purity and fine quality, are saved from choice, selected fruit.

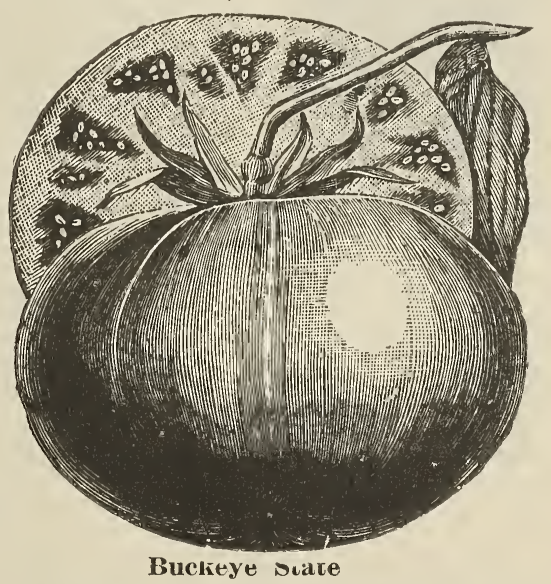

John Baer-Early, brilliant deep red color, smooth, no core, almost free from seed, de. Oz. licious flavor, solid meat, uniform size and ripens to stem. Perfect shipper and remarkably free from blight. Package $10 \mathrm{c}$ each. $40 \mathrm{c}$

Stokes' “Bonny Best"-As early as the Earliana, enormously productive, uniform size, splendid shape, strong vine, plenty of foliage, beautiful scarlet and a good shipper $40 \mathrm{c}$

Sparks' Earliana-Claimed by the producer to be the earlier large tomato in the world. Color bright red. The seed we offer is grown from the original stock $40 \mathrm{c}$

Chalk's Early Jewel-Very fine new sort; large, solid, smooth, bright red, similar to Stone, but earlier 


\section{TOMATO-Continued}

Avon-As early as the Earliana; large, round, slightly flattened; deep scarlet color; smooth, free from cracks and of fine quality.

Greater Baltimore-Midsummer variety, very heavy; extremely firm, thick meat, ripens evenly; free form ridges and cracks; a good canning sort

Crimson Cushion, or Beefsteak-An extremely large, bright red variety of the Ponderosa type; ripens evenly, and of best quality

New Stone Dwarf-Has the same good characteristics of the Stone Tomato; valuable for for its dwarf habits

The Stone-One of the best introduced for years. It is very large, perfectly smooth, and of a fine, bright scarlet color

Londreth's Red Rock-Earlier than the Livingston Stone, extraordinarily solid, smooth as an apple; red as it is possible to be. No sort is its superior in texture or flavor. A heavy producer and an excellent shipper. Recommended especially to the gard. eners and planters, factories for canning, as very showy and productive. One of the finest large, red, smooth tomatoes.

Early Detroit-The largest and best of the early, purplish pink tomatoes; larger than Acme and earlier maturing than Beauty; an exceptionally valuable addition to this class. A splendid shipper

*June Pink-A very early market sort; smooth and of a bright pink color; medium size $40 \mathrm{c}$

* Dwarf Champion-Distinct foliage, grows compact and upright; fruits early and is quite popular

*Ponderosa-The largest variety under good cultivation

Marglobe-An extremely heavy yielding tomato introduced by the U. S. Dept. of Agriculture as of unusual and outstanding merit, on account of its ability to resist rust and wilt. Matures in about 95 days. Ripens evenly. Does not crack. Very meaty. Large, smooth, globular.

Brimmer-Very large and meaty, on the order of the Ponderosa. Package

\section{TURNIP}

(One Ounce to 200 Feet Row; One Pound to An Acre)

For early use, sow as early as the ground can be worked. Rutabaga and other kinds for winter, sow in July and August. Much larger crops are obtained, particularly of the Rutabagas, by cultivating in drills 18 inches apart. The first three named sorts are best for early sowing.

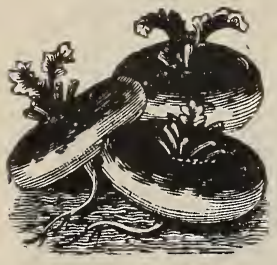

Extra Early White Milan-A new and valuable variety $15 \mathrm{c} \$ 1.25$

Extra Early Purple Top Milan-One of the early variety $15 \mathrm{c} \quad 1.25$ Purple Top Strap-Leaf-One of the best varieties for general use _- $10 \mathrm{c}$

.60

Red Top Globe Shaped-A standard late sort for market and table $10 \mathrm{c}$

Improved Rutabaga-Good for table or stock, hardy and prolific - $10 \mathrm{c}$

Snowball-Small and of rapid growth

Cow's Hom for Stock $10 \mathrm{c}$

Rutabaga, Thornburn Family-Fine-grained and best quality _ 10c

Seven-Top-For green

Family-Fine-grained and best quality $10 \mathrm{c}$

\section{TOBACCO SEED}

Connecticut Seed Leaf-One of the best and surest for this latitude Paper White Burley-Favorite for plug and smoking

Havana Leaf-Thin and fine texture

Yellow Pryor-An old reliable variety, succeeds where other yellow sorts fail

\section{HERBS}

Herbs are available for culinary anā medicinal purposes. They are easily grown, and when preserved by drying are ready for use at any season of the year. Sow in spring as soon as the weather is warm, and thin out as the plants grow up; or, the seed may be sown under the glass, and the young plants afterwards transplanted to their respective bed. Those marked with $a^{*}$ are perennial, and preserved for years. As most of these seeds are small and fine, they should be covered very slightly.

$\begin{array}{lll}\text { ANISE } & \text { FENNELL* } & \text { RUE* } \\ \text { BALM* } & \text { HYSOP } & \text { SAFFRON } \\ \text { BASIL } & \text { HOREHOUND* } & \text { SAGE } \\ \text { BORAGE } & \text { LAVENDER } & \text { SAVORY } \\ \text { CARAWAY* } & \text { MARJORAM* } & \text { TANSY* } \\ \text { CORIANDER } & \text { MARSHMELLOW } & \text { THYME } \\ \text { DILL } & \text { ROSEMARY* } & \end{array}$




\section{BIRD SEED}

Our Bird Seed is put up according to the best formula for the health of the birds; selected from the cleanest and choicest seeds. Ask for prices.

$$
\text { CANARY-HEMP-RAPE-SLNFLOWER-RIRD GRAVEL }
$$

\section{POTATO}

Culture-In order to have the best success in growing potatoes, and to secure a healthy vigorous growth, and a crop free from rot, it is necessary to plant as early as the ground can be made ready. Select a rich soil, and plant in rows 3 feet apart and the sets one foot in the row. To kill the young weeds, run a light steel-tooth harrow over the field lengthwise of the rows. This will allow the crop to get the start of the weeds, besides breaking up all lumps and leveling the ground ready for the cultivator. If wood ashes and plaster can be procured, sow a good dressing over the field after the potatoes are up. If a very early crop is desired it will be necessary to sprout the potatoes before planting. Cut the potatoes into pieces of any size desirable, and place in a warm, light room, from four to six weeks before required for planting in the open ground. During this time shoots will start out strong and vigorous, so that, as soon as planted, they will send out roots and grow much more rapidly than those treated in the ordinary way. Another method is to place the sets in a hot-bed two weeks before they are wanted, and then lift carefully and set out on fresh horse dung, so that the heat will cause them to start at once. If the Colo-

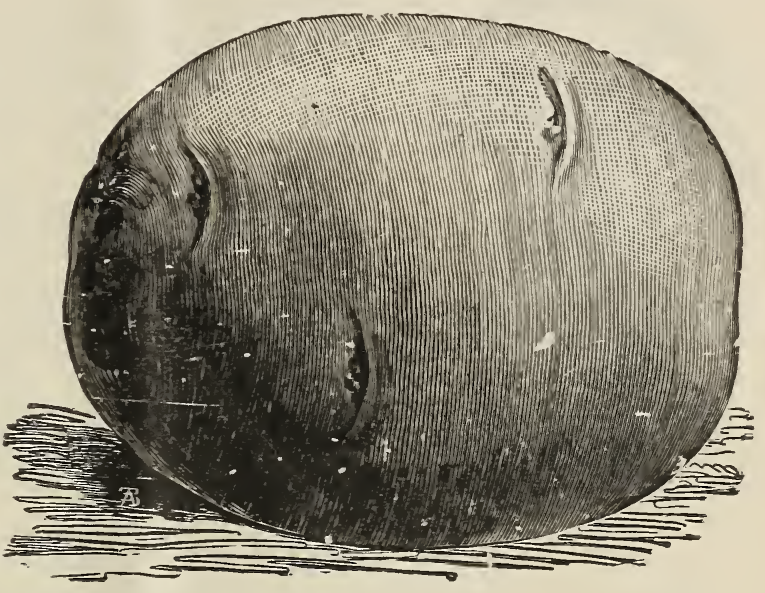
rado potato beetle makes its appearance, the vines must be. dusted with Slug Shot, or dissolve a tablespoonful of Paris Green in a pail of water and apply same with a forcing pump or sprayer.

Scab-In regard to dipping of the Seed Potatoes for scab, the most desirable method is to soak the tubers before cutting for two hours in a solution made up by mixing one pint of 40 per cent iformaldehyde with 30 gallons of water. This preparation can be placed in an ordinary 50 gallon barrel. The best way to dip the tubers in it is to first place them in a sack. After they have been soaked for two hours they must be removed and cut and planted right away, or spread out to dry. With tubers which are becoming fairly well sprouted, it is desirable, although not necessary, to dip them a week or two before planting. One 30 gallon mixture will treat about 30 bushels of potatoes, after which it should be dumped out and a new mixture prepared. To dip large quantities of potatoes in this manner, as many barrels may be kept going as needed.

Red River Early Ohio-This earliest of all varieties, justly belongs at the head of the list; because no variety will mature as early. Some very good early sorts will give eatable size potatoes about as early, but their tops will be green for days after Early Ohio has died. It is the most profitable early market variety.

Irish Cobbler-White netted, early, splendid quality. Eyes strong and well developed; flesh cream white, of excellent quality. Ripens one week later than Ohio. Especially suit. ed for dry climates on account of its deep roots. It is fast becoming the most popular of the early varieties.

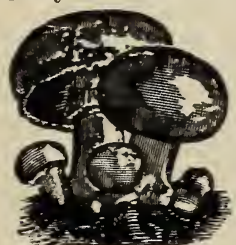

\section{MUSHROOM SPAWN}

Is easy of culture and satisfactory in results. Send for planting directions.

Sweet Honeysuckles, White and Clover Color; Hardy Phlox, Rudbeckia or Golden Glow, Lemon Lillies, well rooted, $25 \mathrm{c}$ per clump. 


\section{Selected Farm Seed}

To our farmer friends we would particularly impress the fact that our field seeds are fresh and thoroughly cleaned, and of high germinating qualities. Our customers are all aware of that and always give us the preference. They know that pure and clean seeds give satisfaction to both buyer and seller.

On account of the fluctuations of the market prices, prices cannot be given on Grass Seeds, Clover, Grain, etc. Prices on Application.

\section{GRASS SEEDS}

The best means of improving meadows, pastures and lawns is to sow a sufficient variety of grass seeds, and we trust our customers will give some of the kinds a trial in connection with Timothy, which hy many is believed to be about the only grass to be sown for hay.

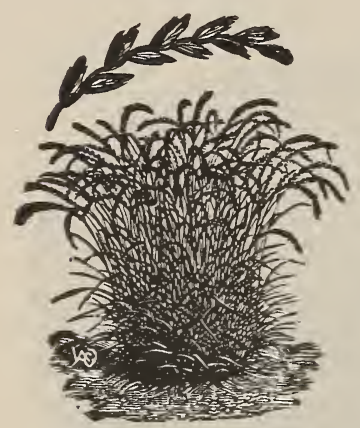

Rye Grass

Timothy-Decidedly the hest grass for hay. Sow one peck per acre.

Orchard Grass-Vraluable for grass and hay; grows in all dry and shady places; sow from 10 to 20 pounds per acre.

Red Top-A valuable permanent grass for meadows and pastures; grows in almost any soil, moist or dry; sow 10 pounds per acre, clean seed. In short, buying cheap seed, money is wasted by sowing, that will not bring returns for the labor.

Kentucky Blue Grass-Best pasturage grass for our soil and climate. It is most valuable for lawns, yards, etc., combined with some white clover. For pastures, sow 20 pounds, and for lawns 50 pounds of clean seed per acre.

English Rye Grass-Is the staple grass of Great Britain, entering largely into the composition of many of the richest meadows and pastures. Its natural adaptation is almost all cultivated soils, and its early maturity are the reasons it has hitherto been so extensively cultivated in preference to many other equally nutritious sorts.

\section{CLOVER SEEDS}

Clover, and in fact all Leguminous Plants such as Cow Peas, Soja Beans, Vetch, etc., is a blessing to recuperate worn-out land which needs nitrogen furnished by the air. If your land is sour, correct by sowing lime.

In purchasing clover, as well as any other seed, always buy the best quality that is possible to procure; although the price may seem high, it is much cheaper than buying a poor quality at a low price. The low price seeds are usually badly cleaned, of poor germination, and very often contain weed seeds of other plants.

Red Clover-Will succeed in any soil; sow 6 to 8 pounds per acre.

Alfalfa or Lucerne, Clover-Is perennial and lasts from 8 to 10 years; the roots penetrate from 10 to 15 feet into the ground. For a permanent meadow it does best on alluvial soil. Sandy loam with a porous underground, so that water passes off rapidly, is preferable. Hard pan and wet underground is fatal to the plant. As a hay crop it has no equal, and the feeding value of number one alfalfa is equal to bran at $\$ 17.00$ per ton. It should be sown here from the 15th of August to the 10th of September. Plow the ground sometime previous, making a fine but not too deep seed bed. Sow from 15 to 20 pounds per acre, and run the smoothing harrow over once or twice. In spring it may be sown in April after severe frost is past, but in doing so you have weeds to contend with, and which may smother the young weak plants. In this case mow the weeds when they are 6 to 8 inches'high, and not remove them, but let them lay on the ground. A thick stand is desirable, otherwise hay will be too coarse. Cure alfalfa hay as you would Red Clover, and save all the leaves possible. It may be cut three times during the season. It is claimed by many agriculturalists that Alfalfa does best on a former Red Clover field on account of containing the needed bacteria.

The Alfalfa we have in stock is of the very best and purest quality, free from obnoxious weeds, which you will find universally in cheap seed. Sow Alfalfa by itself.

Alsilke, or Swedish Clover-Perfectly hardy, does not heave in winter or spring from frost; stands drouth well, and in many respects superior to common red clover. It affords a large return of hay; is excellent for soiling and unsurpassed for the honey bee. When the plant is once established it will remain for many years in full vigor. Is at its best in a moist situation and alluvial bottom soil. It is much liked by cattle and well suited to land liable to wash, for reason of its long and spreading roots holding the soil. It certainly would pay any farmer to try it. Alsike also produces a valuable and heavy crop of seed. Sow 5 to 6 pounds to the acre. 


\section{WHITE SWEET CLOVER}

(Melitlitus Alba)

White Sweet Clover, or Bokhara Clover, as it is called, is a liardy biennial plant, erect and branching in growth. It starts up very early in the spring, and in its second year it reaches a height from 5 to 12 feet, blooms, matures its seed and dies. However, there is usually enough seed scattered to reseed, and the crop is continuous unless cut before the seed ripens. When young, the plants resemble Alfalfa very closely. Sweet Clover has a peculiar bitter taste, and the flowers and leaves a sweet vanilla-like odor by which it is easily distinguished.

It seems to grow in all climates and with little regard to the character of the soil. It is found growing in gravel-pits, heavy clay soils, and sometimes in almost pure sand. Nor is it often found growing in low wet. soils.

It sends it roots to a great depth. It is a legume like Red Clover and Cow Peas and like these plants has the faculty of extracting nitrogen from the air and storing it up in the roots, thus fertilizing the soil for the use of succeeding crops.

It is a valuable forage crop; while some animals refuse it at first because of its peculiar taste and odor, they soon learn to like it and thrive on it. In food value it does not differ greatly from Alfalfa. The crop may be pastured closely and there is little danger of bloating. For hay it should be cut just as it is coming into bloom and is handled much the same way as Alfalfa. A second cutting can usually be secured 40 to 60 days later, if not pastured. It is also used to some extent as an ensilage crop put into the silo and fed successfully in this way.

It is an excellent plant for bee pasture, as it blooms continuously from June to October. It is not troublesome in cultivated fields and can usually be destroyed by mowing in full bloom.

The seed may be sown on the bare ground during the winter, with spring grain crops during March, or on well prepared ground during April and May. It requires a firm seed bed with just enough loose soil on top to cover the seed. About 15 pounds of clean hulled seed are required for an acre.

\section{SUDAN GRASS}

Sudan Grass is strictly an anriual, and dies each year like Millet, and must be seeded again each spring. This makes it fit admirably into any system of rotation, and while it does not benefit the soil like legumes, it does afford a change in crop, and this is a good thing for the soil. Sudan Grass is tall, reaching a height of from seven to nine feet. The stems are very small and are rarely thicker than a lead pencil. The plant stools wonderfully and produces under favorable conditions as many as 100 stalks from a single root.

Harvesting-Sudan Grass is easy to cut with a mower, and cures readily, so that the haying process is much the same as that of Millet or any other hay grass. Where it is harvested for seed, an ordinary grain binder is best suited for handling the crop. When cut for hay it is best to cut after full in bloom, so that it will have as much time as possible for a second growth. After cutting it renews its growth promptly when moisture conditions are favorable, and in about 40 to 50 days another cutting is ready. The grass stools abundantly after first cutting, and the second and third cuttings are very fine stemmed.

\section{GERMAN MIILET}

COMMON MILLET

DWARF ESSEX RAPE

CANE OR SORGHUM

AMBER-ORANGE

KAFFIR CORN

MILO MAIZE

CANADA FIELD PEAS

COW PEAS

SOJA BEANS

BUCKWHEAT, ETC. 


\section{Formation of Lawns from Seeds}

$\mathrm{T}$

HE GROUND should be thoroughly drained and well prepared. The soil ought not to be too rich, as a rapid growth is not wanted in the grasses of a lawn, but the surface should be as much alike in quality as possible. After sowing, the ground should be rolled and cross rolled, in order to press the seed firmly into the soil. The proper time to sow grass seed is from March 15 to April 15. Seed also may be sown in the fall, provided it is done early enough to secure a good strong growth before winter sets in. The sowing should be done when the ground is moist, or before an expected rain, cover lightly with soil; a subsequent rolling or firming the ground with a roller or heavy board is always advisable. As to weed seeds in newly made lawns, it may not be generally known that many weed seeds actually lie dormant in the ground for five or six years and will germinate and make their appearance when the soil is turned up. The annual wild grasses such as Crab Grass or Summer Grass must be pulled up by the roots before they ripen their seed in the fall. This is the only way to rid lawns of these pests. Rolling and dragging, however, should not be done when the soil is very wet.

ROLLING-As soon as the frost is out of the ground in the spring, the land should be gone over with a heavy roller. Winter frosts loosen the soil and rolling is necessary to com. press it again. If grass seed is to be sown, this should be done first, and the rolling immediately afterwards. Frequent rollings are recommended.

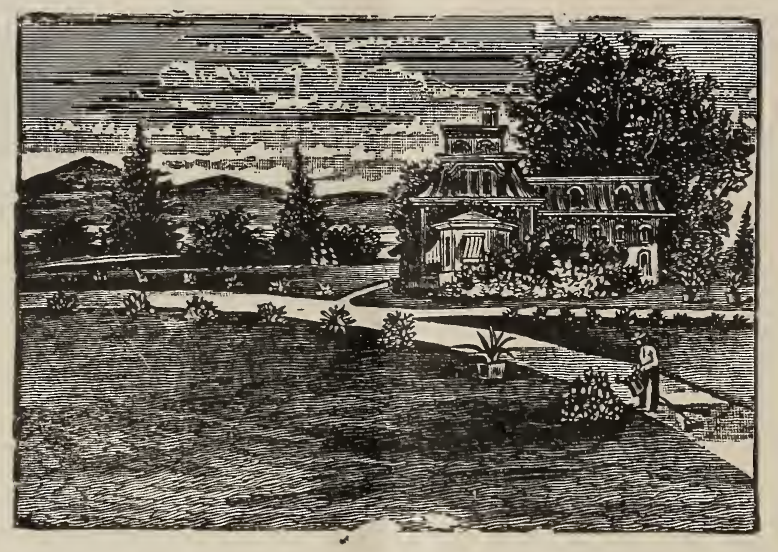

MOWING-All turf-forming grasses are improved, both in vigor of root growth and in fineness of texture, by frequent mowings, but not before the grass is strong and firmly rooted. It is impossible to say just how often the grass should be moved, as that depends upon the rate at which it grows. Too closely cutting should be guarded against, however, especially during the hot summer months, when the roots require some top growth to protect them from severe winter frost. Mowing should therefore be discontinued in time to let the grass grow pretty long before the winter sets in. If watering is needed do it thoroughly.

\section{OUR SELECTED́ LAIVN GRASS SEED}

Contains, besides Bluegrass, a composition of the finest perennial or lasting grasses which will, in the shortest time possible, produce a beautiful, compact turf, enduring the summer heat and insure a rich deep green sward throughout the season.

This mixture is absolutely free from obnoxious weeds, and no better can be offered by any Seed House.

Bluegrass sown alone perfects itself the second year after being sown.

Do not be sparing of seed. From 50 to 75 pounds to the acre, or one pound for $20 \times 20$ feet, is little enough. More seed is needed on poor soil than on that which is rich.

For Shady Places-We have a special mixture for this purpose.

Dock, Dandelion and Plantain, natural to the soil, spring up spontaneously; are most troublesome, and should be watched and exterminated on appearance.

Sour Ground-Sometimes the soil of a lawn gets sour by too much shade; in this case an application of one-half lawn fertilizer and one-half lime is one of the best remedies. 


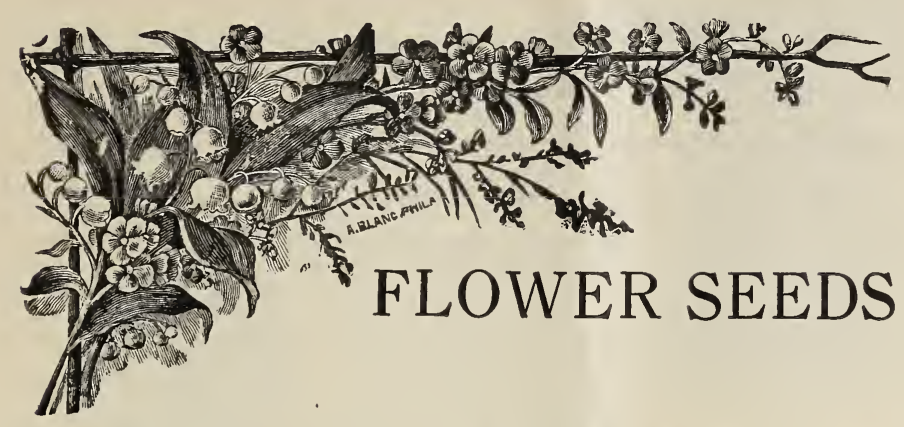

Encouraged by the Many Flattering Testimonials from Our Customers, We Are Offering a Particularly Large and Fine Assortment of

\title{
CHOICE AND RELIABLE FLOWER SEEDS AND BULBS
}

\author{
Mostly Our Own Importation and Adapted to Our Climate
}

NO OLD SEED OFFERED

\section{BRIEF HINTS ON SOWING AND CULTIVATING READ CAREFULLY}

$\mathrm{T}$ HE GENERAL RULE for sowing flower seed, as well as any other seeds, is to sow them at the proper depth-and the depth at which they are sown should in every instance be governed by the size of seed itself. As the sprouts of small seeds are naturally small, if sown deep as large seeds they will be either unusually long in starting -or more likely perish in the ground after starting, for want of sufficient strength in the young sprouts to force a passage through the soil. Very small seeds, such as Portulacea, Campanula, Digitalis, etc., should be merely sprinkled over the surface of the ground, after making quite smooth with the back of a spade, and barely covered with finely sifted, light mellow soil, and afterwards protected from the scorching sun and heavy rains by a cloth, mat, or some green branches stuck around it.

In transplanting plants it is important to cut back branches and leaves, in order to secure thrift and good shape.

Another great object to be considered is the soil into which the flower seeds are to be sown. The soil best adapted for flowering plants generally is a light, friable loam, containing a sufficient amount of sand to render it porous. Deep digging and enriching with thoroughly decayed manure is the least that should be done. If the weather, after sowing, should be dry, it will be necessary to water the places where the seeds are sown with a fine watering pot, regularly, but slightly every evening, as it is essential that the seeds during the process of germination should be kept constantly moist. From a neglect or oversight of this arise most of the failures. As the process of germination is shorter or longer in the different kinds of seeds, the patience of the cultivator is often sorely tried with seeds of a slow germinating character. The patience of a devoted florist, however, never exhausts ill these manipulations, and the certainty of his final success repays him fully for the little trouble.

Afterwards, when one or two inches high, the young plants can be removed on a rainy or cloudy, damp day to permanent positions; here the earth must be carefully prepared for their reception, being especially enriched by a previous application of very short, well rotted stable manure or compost.

In the after culture, the most important matter is to keep the clumps well thinned -for crowding will defeat all other preparations, while space, which at first seems four times too much, will serve to develop robust plants, which by their ample leafage, are well developed flowers, will amaze people not familiar with the conditions necessary to successful plant culture.

If Worms are found on the roots of House and Pot Plants, take half pound of fresh lime, dissolve it in one gallon of water. As soon as the lime is dissolved and its sediment settled, pour off the clear water and apply the same to the plant to saturate all the soil, and repeat as often as necessary.

Too much and too little watering are both injurious to the plant. The only rule is, when the soil in a pot looks dry on its surface, apply milk-warm water enough to saturate all soil in the pot, then wait until the soil looks dry again before applying more. Flowers bloom freely if plucked often.

Look out for insects, such as aphis, red spider, scales, etc. They multiply fast. For remedies and fertilizer, see Page 37. 


\section{Choice Flower Seeds}

\section{Prices: Unless Specially Marked, Price for Postage Paid:}

\section{Directions for Sowing are Printed on the Different Seed Packages \\ EXPLANATION OF THE MARKS}

"a" represents "annual," lasting one year; "p" represents "perennial," three or more years. A large number of Biennials and Perennials, if sown early, flower first season; " $h \mathrm{~h}$ " "half hardy;" "t" represents "tenđer:"

Our packets contain twice the amount of good, reliable Flower Seed than the common trade papers.

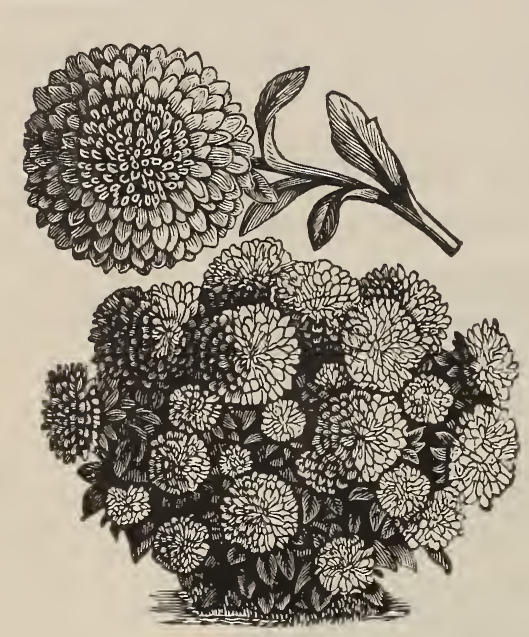

Aster

Aster (hha)-Seeds are saved from the finest double sorts. There is nothing finer than a bed of these in autumn. They need cool weather with a touch of frost in the air to bring out their colors. Seed may be sown in open ground in May to bloom finely in September and October, when the flowers are seen at their best. For earlier blooming sow under glass or special hot-beds in March or April. Sow seed one-half inch deep in rich, light soil. Transplant two and three times, eighteen inches apart each way. Do not use fresh manure. A small portion of unslacked lime or wood ashes keeps insects from the roots.

Victoria, or Truffaut-It produces the most beautiful and perfectly formed flowers of pyramidal habit, and is also the best for culture. In colors and mixed. Paper, $10 \mathrm{c}$.

Crego Giant Mixed-A beautiful flower of largest size, with very large petals which are very attractively curled and twisted. Plant branching and very vigorous, with long, strong stems; very desirable for cutting. A mid-season sort, considered by many as decidedly the best aster yet produced. Package, $10 \mathrm{c}$

Semples Branching-A class of Asters useful for cut flowers; they are very large and double; borne on long stiff stems, and the color's are clear and handsome. Price, per paper, $10 \mathrm{c}$.

We also have fine mixtures in all colors. Per paper, $5 \mathrm{c}$.

Vick's Branching,Vick's Royal, Vick's Rochester, Vick's Comet. 25c package.

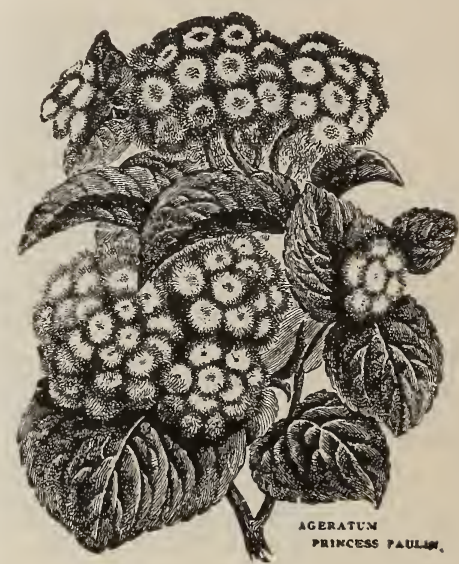

Ageratum (hha)-Exceedingly charming, free blooming bedding plants, and planted among Geraniums and Alyssums. For early blooming, sow under glass. It is one of the few blue flowers which blossom all summer. Cover seeds lightly.

Alyssum (ha)--For b o r d e rs, edgings, baskets, pot, rockwork and for cut. ting, we recommend a liberal use of this dainty little flower. In borders sow thickly so as to form masses, and quite early in the spring or even the previous autumn For winter bloom sow late in August, and thin the seedlings to about a dozen for a good sized hanging basket. Cut back after the first flowers fade and others will come. 
Balsam (hha)-Most magnificent annual, producing masses of rich colors; transplanting has a tendency of making the flowers double.

Balloon Vine (hha)--A pretty white climber with green fruit.

Delphinum or Larkspur (ha)--Handsome for any garden; of easy ulture; a rich loam will produce its finest plants and flowers of various colors.

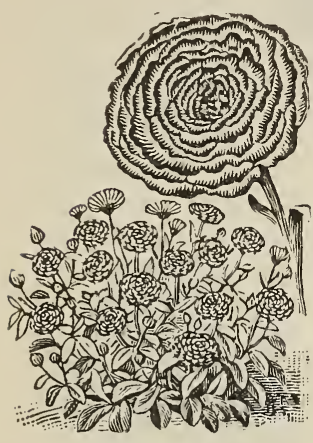

Calendula

Cosmos - Beautiful autumn blooming plants. They produce thousands of beautiful

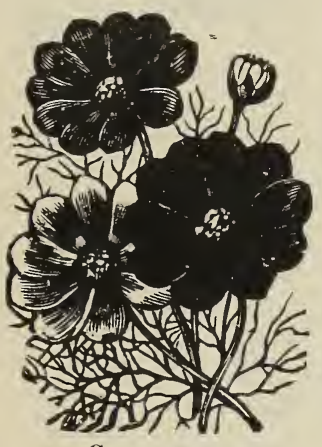

Cosmos
Calendula (ha) Hardy annual about à foot high. The seed may be sown in open ground quite early in sprins -and they bloom early in summerand continue until late in the autumn The flowers exhilit every shade of yellow from ivory to deep orange, are producing in great profusion and are strongly effective in bed borders or back grounds.

fl owers in pure white, pin $\mathrm{k}$ and crimson shades furnishing an abundance of cut blooms for autumn decorations when other flowers are scarceShould be sown in spring in the open ground and afterwards transplanted. Plant not less than one inch apart in rows or in masses in beds. When the plants are about a foot high the tops should be pinched out to induce a bushy growth. They prefer a rather light, not too rich, soil, but do well almost anywhere. They should be in every garden.

Cosmos-Lady Lennox.

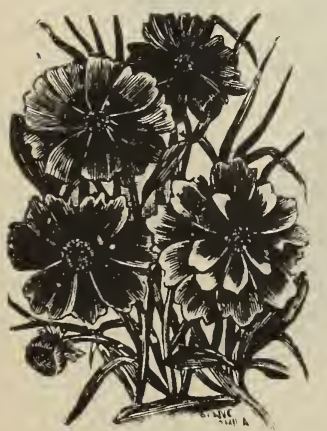

Calliopsis, or Golden Wave (h a)

Fine showy plant, abundant in bloom, and of bright colors; fine for cut flowers. Do not fail to have this beauty in your garden.

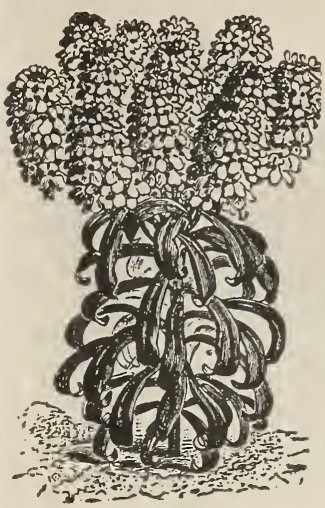

Candytuft

Candytufts (h a)The Candytufts are among our best white flowers for edgings, for bedding o r massing, for rockeries and for cutting. Several of the varieties a re fragrant and all are profuse in bloomSow outdoors in April where they are to bloom, and thin well when the plants grow about an inch. Sow again in a month, and late in July for flowers.

Columbine (h p)- - They are fine, early, free Howering, hitrdy, border plants, showy and ornamental. Every garden should have them.

('anary Bird Flower (hlia)-Firm climber.

Centaurea-Cornflower (ha)-C. Cyanus is

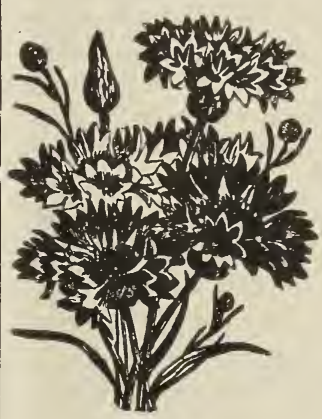

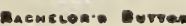
also known as Blue Bottle, Kag:ed Sailor, Kaiser Blumen, and sometimes as Bachelor Button These plants of the hardiest nature and simplest culture and esteemed among the most attractive and graceful of all the old-fashioned flowers. When placed in water the flower's increase in size.

Margaritae-Pure white, $2 \frac{1}{2}$ in. across, exquisitely lacinated and delightfully scented; form stocky, well budded little bushes. A garden treasure, $1 \frac{1}{2}$ feet. Paper $10 \mathrm{c}$.

Centaurea Americana Gigantea-A giantflowering Centaurea, with white or lilac-tinted blossoms, fully four inches across. The petals are so constructed as to resemble rich lacework. Perfectly magnificent and is a great favorite where it is known. It is rare, however, though one of the easiest of hardy garden flowers to grow. Extra fine for cutting, and the flowers command a ready sale. 10 cents.

Cardinal Climber (Ipomoea Cardinalis)Annual Climber-A splendid, new, brilliant climber of great value. A strong and rapid grower, attaining a height of 20 to 30 feet with beautiful deeply lacinated leaves, and just covered with intense cardinal red flowers from mid-summer till frost. Flowers measure $1 \frac{1 / 2}{2}$ to 2 inches across and are borne in clusters of 5 to 7 blooms each. The leaves resemble those of a fine Japanese Maple. They cover the vines completely and give good shade, admitting, however, plenty of air when planted on the porch. The brilliant scarlet flowers are borne profusely. Pkt., 10c. 


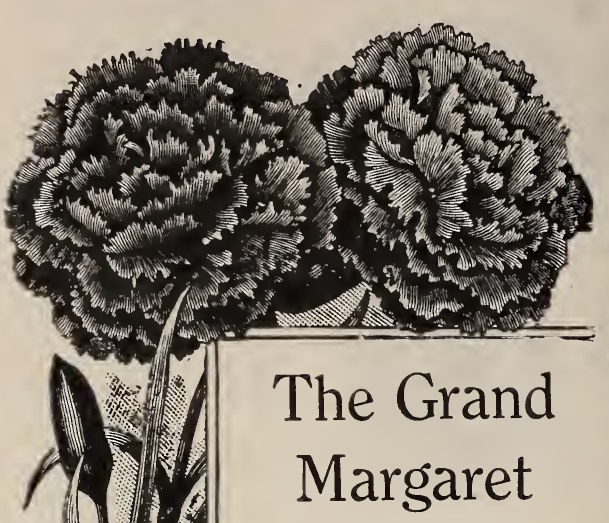

SHOCLD BE IN EVERY GARDEN

\section{Paper 10c}

Margaret Carnation - This grand, new strain of Carnation surpasses all others for the beauty and loveliness of its incessant bloom. The advantage of having it afford a great profusion of bloom the whole year round can well be appreciated by all lovers of this beautiful flower. Seed in autumn and the plant will increase in size and beauty until frost. Taken up and potted, they make beautiful house plants. Stalks grow eight or ten inches high and are always covered with a mass of buds and bloom. It is highly prized for window ornaments; also cut flowers. The colors range through all shades. Highly scented.

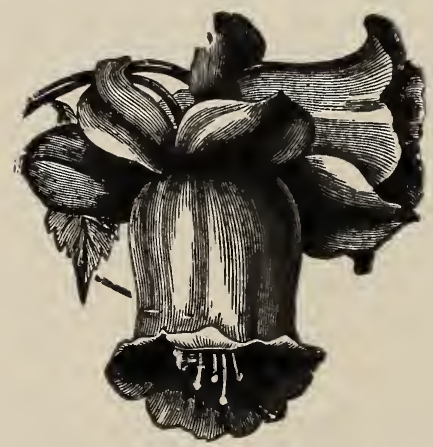

Cobea Scandens

Cobes Scandens (t p)-A fine, rapid growing climber; dark foliage; purple, bell-shaped flowers; will run from twenty to thirty feet in one season. Plant seed where wanted in early part of May. Most satisfactory for porches and trellises.

Cardinal Climber-Similar to Cypress Vine but larger flowers.

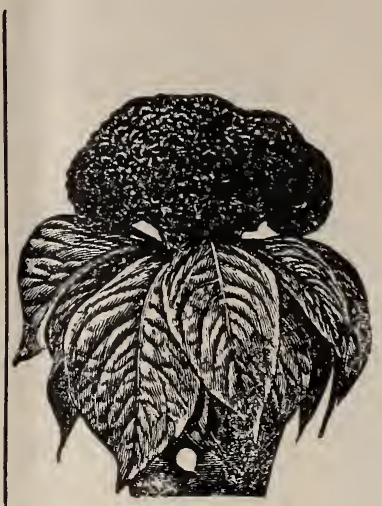

Cockscomb (h a) - Th e bright red and crimson varieties are most effective, both in gardens and in winter boquets for which they are cut before fully ripe and dried in the house. Dwarf varieties make novel and attractive border. The tall ones form striking groups. Transplanting into rich soil about the time the combs begin to form makes these flower-heads larger.

Chinese Woolflower-(Celosia Childsii)-A distinct form of the plumed Celosia, with beautiful ball-shaped flower heads of a purplish crimson color, somewhat resembling a ball of wool. It flowers profusely during the summer and fall. Two to three feet tall. One of the finest fall-blooming annuals. Pkt., 10 cents.

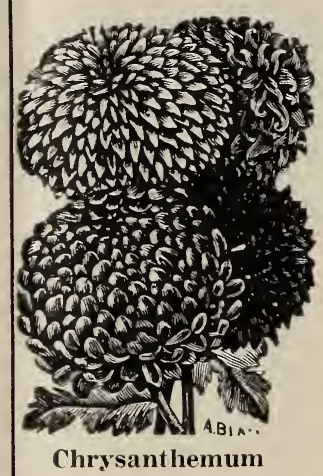

ChrysanthemumThe annual Chry$\mathrm{s}$ a $\mathrm{n} \mathrm{t} \mathrm{h}$ emums are showy free bloom. ers, and should be grown in gardens in large beds, where they will show their bright colors finely: Perfectly hardy and ve r y desirable. A multitude of fine colors and shapes. Tobacco dust will destroy the black flea if attacked.

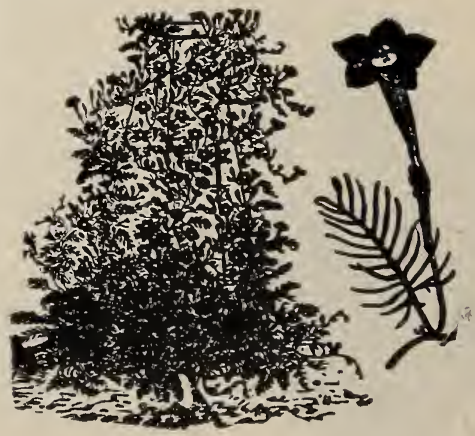

Cypress Vine-Tender annual climber, graceful foliage, with small red and white 
star-shaped flowers. For early flowers sow in hot-beds, pots or boxes, under glass and transplant to deep and rich soil as soon as danger of frost is over, when sowing may be made in the open ground for later blooming. The seed is hard and horny and should be soaked in hot water before sowing.

Daisy-The poet's favorite; very popular; fine for edging and borders; prefer a cool, shady place.

Digitalis or Fox Glove (h p) - Beautiful, showy border plants, very ornamental particularly when planted among shrubs.

Eschscholtzia ( $\mathrm{h}$

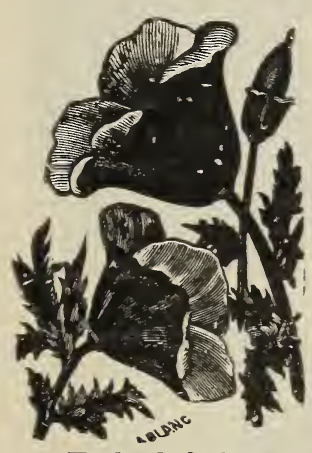

Eschscholtzia a) of Califormia. An annual incomparably bright and rich in its pure tints of yellow and orange and shades of red. The plants average about one foot in height, have beautiful silver foliage, and produce their large poppy - like flowers quite lavish. ly from early spring until frost. These sowings may be made early in the spring or late in the autumn; for early germination and blooms, the next spring. Also very useful as a pot plant and for cut flowers.

Feverfew or Matricaria - Free flowering hardy plants, succeeding in any garden, easily cultivated; blooms until frost; hardy biennial; 18 inches.

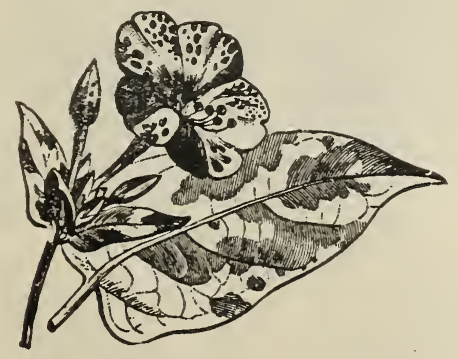

Four 0'Clock (t a)-Handsome, free flowering, fragrant, blossoms variegated, striped and various colors; easily cultivated; planted in masses, they present a gorgeous sight during early morning and afternoon. Should be in every garden.

Forget-Me-Not (hh p)-Beautiful and wellknown, delicate flowers. Grows best in a moist situation.

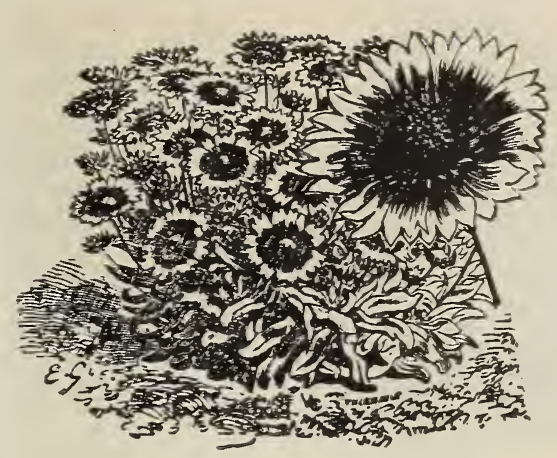

Gaillardia, or Blanket Flower

Gaillardia - Splendid, showy annuals remarkable for the profusion, size and brilliancy of their flowers, continuing in bloom from early summer until November; excellent for beds, borders or for cutting; should be sown where they are to bloom. 11/2 feet.

Gypsophila (h $\mathbf{p}$ )-Fine for boquets; free bloomers; for rockwork or shrubbery, and will grow in any soil.

Gourds (t a) - Excellent for covering verandas or trellis work, and for training over arbors, fences, etc., cultivated like squashes and should be started in hot-bed or house.

Sugar Trough or Sap Bucket - Holding from four to ten gallons; strong, durable and light.

Nest Egg Gourls - Resemble in color, shape and size of a hen egg.

Dishcloth-And a most admirable one is

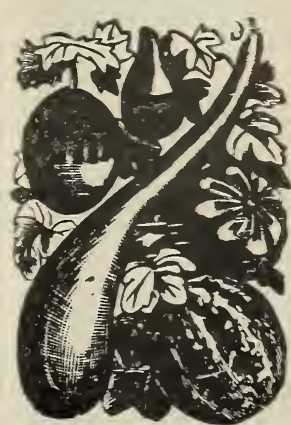

Grourds furnished by the peculiar lining of this fruit, which is sponge like, porous, very tough, elastic, and durable. Many ladies prefer this dishcloth to any other. The fruit grows about two feet in length and the vine is very ornamental, producing clusters of large yellow blos som s in pleasing contrast with the silvery shaded, dark green foliage. In the north this variety should be started in a hot-bed.

"Knob Kerrie," "Calabash," or Pipe Gourd, Dipper Gourd, Bottle Gourd, Spoon Gourd, Hercules Club.

Heliotrope - Highly valued for their delightful fragrance. Is sown in open, warm groud. It flowers in August. 


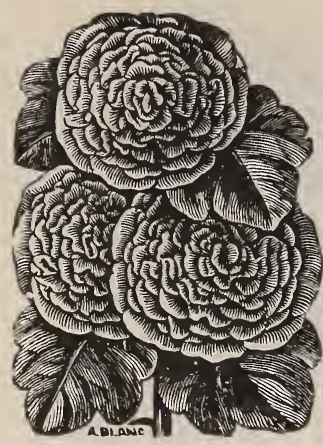

Hollyhock
Holly hoc k$\mathrm{H}$ a $\mathrm{r}$ d y perennial and should be in every garden.

The Everblooming A 11 e g heney and Carter's Superb are particularly fine and most desirable. May be sown as late as August to flower the following year. It is advisable, however, to sow every year, as the flowers on young plants are much more vigorous than on old ones.

Hyacinth Beans (t a)-A fine climber; plant seed where desired to bloom.

Lobelia (h h a)-Fine for beds, edgings, ribbons, borders and hanging baskets; of easy culture.

Mignonette (h a)-A well known favorite; highly scented and flowering freely. If wanted in winter, seeds should be sown in July.

Moonflower (t a)-Ipomoea Noctiflora, or Grandiflora, Ala. This is a variety of which plants have been so extensively advertised the past few years. For covering walls or porches or trellises, particularly the latter; when over paths their beautiful pure white, moonlike flowers (which are often six inches in diameter) are seen to great advantage. It is an exceedingly rapid flower. In rich ground, in a sunny situation the plants readily grow 25 feet high in a season. Soak seed 24 hours. Scrape off the pointed end with a pen-knife before planting. Paper, $10 \mathrm{c}$.

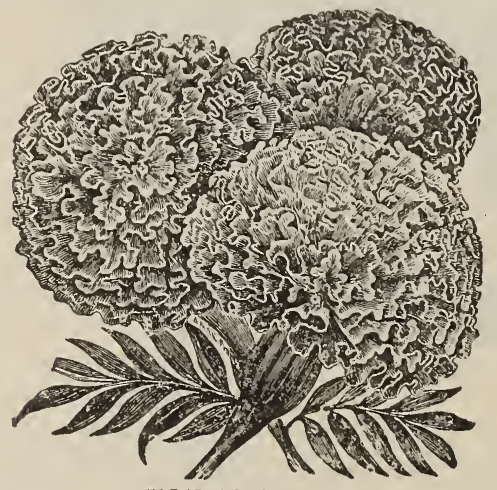

Marigold (h a)-These, like the Calendulas, are valuable because they light the gardens with such a grand glitter of yellow far into the frosts of autumn. The dwarf varieties make a fine border for taller sorts, and both are effective when placed in groups or in garden borders.

French Dwarf-Small, yellow, brown and striped flowers.

Tall Africall-Large, double lemon and orange color.

Eldorado-Large, quilled, perfectly double; brilliant shades or orange yellow.

Mourning Bride, or Scabiosa (h a)-The Mourning Bride is a showy border plant, with beautiful variegated flowers. It succeeds in ordinary garden soil. Minor Aurea is a beautiful golden yellow; new variety.

Nigella, or Love in a Mist (h a)-Curious and ornamental; fennel shaped leaves; easily grown and hardy.

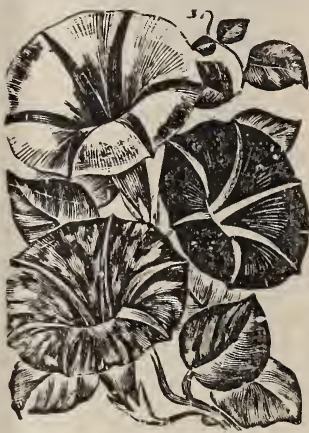

Morning Glories
Morning GloriesThe surpassing charm of this JAP. ANESE MORNING GLORY, entrancing to beauty and gigantic size of the flowers; they measure from 4 to 6 in. across. The colors of the flowers-the shading and markings are limitless. Paper, 10c.

Tall Morning Glory-The well-known, oldfashioned climber. It is easy to grow and should be planted early.

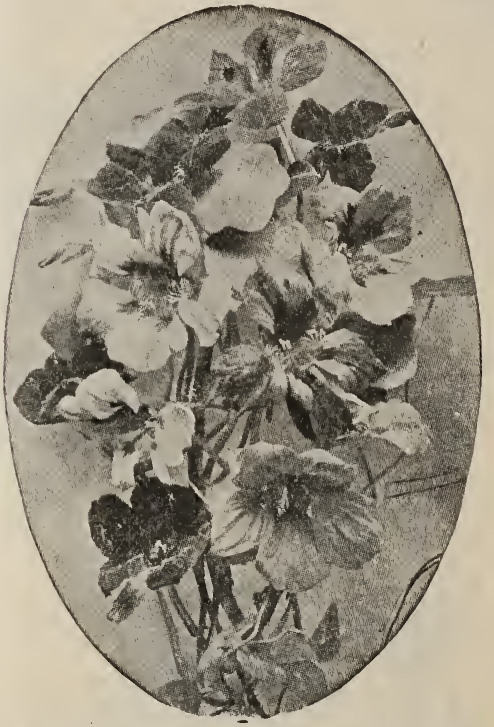

Nasturtium, or Kapuziner Cresse (h a)Beautiful bedding plants. Planted in poor soil, they flower profusely and for a long time. The color of flowers cannot be excelled. Dwarf varieties should be planted so that they will contrast with white and blue flowers. We have a large variety of the choicest sorts. The dwarfs are among the most useful and beautiful annuals for bedding and massing, while the tall sorts are admirably adapted for rock work. Soil need not be rich. Color mixed, $15 \mathrm{c}$ per ounce; in separate colors, in white, yellow, gold, orange, pink, red, crimson, brown and spotted, $20 \mathrm{c}$ per ounce. 
Chameleon Nasturtium-Tall and Dwarf. When in full bloom you can find every shade of color and form of marking known in Nasturtiums. No matter what color a flower may be when it opens, it changes color continually until it fades. The Chameleon Nasturtium is always curious, handsome and attractive. $20 \mathrm{c}$ per oz.

Lobb's Nasturtium-Brilliant and profuse in colors and flowers; a trifle smaller than other sorts; height 6 feet. 20c per oz.

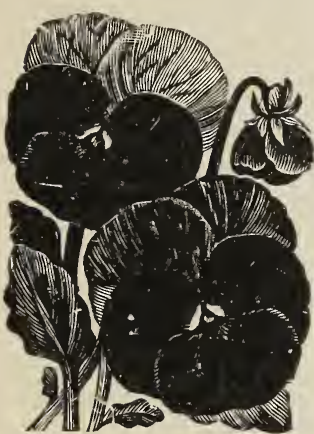

Pansies
Pansy - The pansy is a popular flower, with both florist and amateurs, giving an $\mathrm{a} b \mathrm{und}$ a $\mathrm{nce}$ of bloom until frost, enduring our hard winters with surety when covered, and greeting us in the earliest spring with a profusion of $\mathrm{v}$ e $\mathrm{r} \mathrm{y}$ bright blossoms. It will flower better in summer if planted

where it is somewhat shaded from the sun and furnished with a good supply of water, but in almost any situation will give fine flowers in spring and autumn. Pansy seed may be sown in the hot-bed or open ground; if sown in the spring, get in as early as possible, so as to have the plants in bloom during the early rains. Seed sown in cool places in June or July and watered until up, will produce fall flowering plants; if sown in October they will flower in early spring. To have good flowers the plants should be vigorous and make a rapid growth. Young plants give the largest flowers. Pansy seed is a specialty with us, and it is the best that can be had. Giant Trimardeau and Cassiers, per paper, $10 \mathrm{c}$.

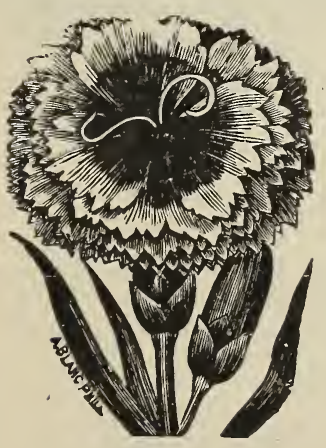

Pink
Pink (Dianthus) Beautiful and ornamental g e n u s; f o $r$ beauty and sweetness contains some of the most prizes flower's we possess. The leaves of the hard $y$ perenials are green all winter. Many can be grown in pots and kept in the house. No garden $\mathrm{should}$ be without some of the varieties of the Dianthus familywhich for color and fragrance cannot be surpassed. Pinks succeed well in any fairly rich soil, but when the production of large flowers is aimed at, a richer soil should be prepared.

Hedewigii-(Japan Pinks)-Usually large and brilliant; oddly edged striped. Paper, $10 \mathrm{c}$.

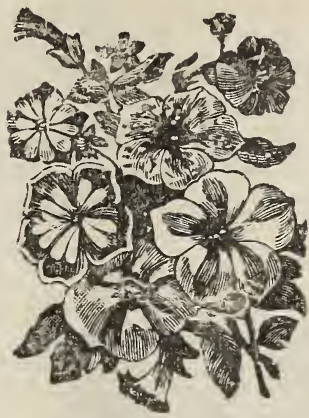

Petunia

Petunia (h h p) Highly ornamental --easy in cultivating--beautiful flowers of all colors. c o n t in u ing to bloom until frost. There are no better plants than the petunia for beds, borders, window boxes a n d vases. Cover seed slightly. See Page 27.) Double and Star petunias. Per paper, $10 \mathrm{c}$.

Balcony Petunias-For window boxes or porch boxes, dry banks, terraces, or among rock work, the Balcony Petunias may be depended upon to supply an unsurpassed floral effect throughout the summer until frost.

Balcony Blue-The flowers open up as a rich purplish blue, turning more reddish as they age. Pkt., 10c.

Balcony White-A magnificent pure white The flowers are not only very large, but are borne abundantly, blooming until frost. Pkt., 10c.

Balcony Rose-Bright rose flowers with yellow throat. A profuse and continuous bloomer. Pkt., 10c.

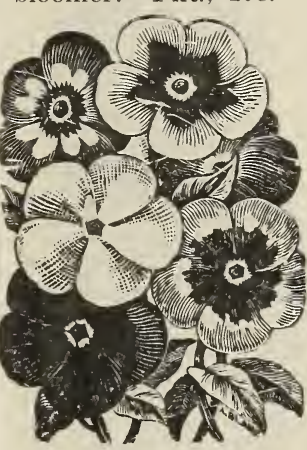

Phlox Drummondii
Phlox Drummondii or Flame Flower (li a)--A bed of these will be highly prized for unrivaled richness and brilliancy of color and profusion of bloom. By making several sowings they will bloom until frostAlso fine for pot culture. If sown too thickly they will suffer from mildew. Cutting away the flowers and seed pods make plants more bushy, and bloom a longer time. The Star of Onedlinberg. Per paper, 10c.

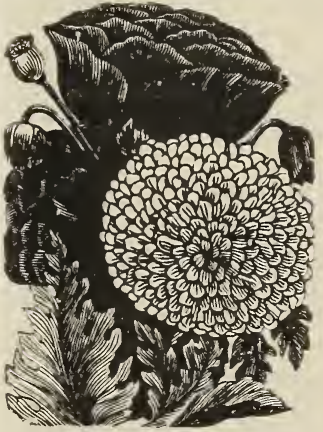

Poppy
Poppy - V e r y showy and free flowering. For beds with a background of green, there is nothing finersome sorts are admirable for naturalizing wood $\mathrm{y}$ spots. They are also fine for cut flower use. Should be $\mathrm{ke} \mathrm{p} \mathrm{t}$ from forming seed to sec u re continuous flowering. $\mathrm{T} h \mathrm{~h} \mathrm{y}$ are easily cultivated; the most suitable soil being sandy loam. Cover seed very lightly. Deserves a place in every garden.

The Shirley-Is a magnificent variety, unsurpassed for beauty and color. 
Cardinal-Compact, or robust habit and brilliant variegated, in scarlet and white.

Oriental-Perennial and hardy, large scar. let flowers. Per package, $10 \mathrm{c}$.

Portulaca or Moss Flower, Double and Single-Should be in every garden. There is scarcely any flower in cultivation that makes such a dazzling display of beauty as a bed of many hued, highly colored flowers.

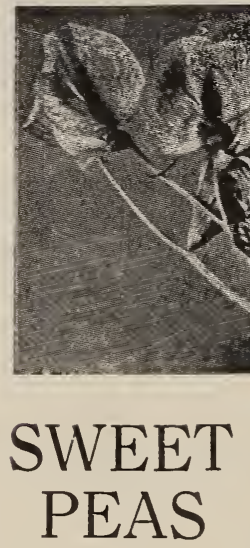

0 u $r$ collection of Sweet Peas cannot be surpassed by any house, no matter by whom they are off e red. It is the cream of the Sweet Peas.

Nothing can be finer than a hedge of Sweet Peas. The rariety of color and the sweet-scented flowers make them desirable for every garden. To bloom early, seed should be planted very early in the spring. The most approved method of cultivation is to sow in a trench five or six inches deep, covering them at first with one inch at a time. After the plants are grown up, fill in the earth about them. After the plants are well grown up, they should be watered copiously, and bone meal worked into the soil about the roots is recommended.

\section{BELOTY FIND THE NAMES OF ONLY A FEW OF THE LEADING VARIETIES}

\section{Spencer Varieties}

These are known for their unusually largesized flowers, and for the waved or fluted appearance of the petals. 'They' are also frequently referred to as Orchid flowering Sweet Peas.

Apple Blossom-Crimson, buff and pink.

Osta-Ohn-Lavender tinted mauve.

Helen Lewis-Crimson, orange and rose.

John Ingham-Rose-carmine.

Othello-Rich, deep maroon.

White Spencer-Pure white.

Countess Spencer-Soft rosy pink.

Beatrice Spencer-Deep pink.

George Herbert-Rose magenta.

Tennant-Purplish mauve.
THESE FOLLOWING VARIETIES ALL 5c PER PACKAGE

Mont Blanc-White; very early.

Emily Henderson-Pure white.

Wonder-Double white.

Mrs. Kenyon-Large yellow.

Queen Victoria-Primrose yellow.

Majestic-Deep pink.

Katherine Tracy-Brilliant pink.

Countess Spencer-New, beautiful rose pink; one of the best.

\section{Apple Blossom.}

Janet Scott-Pink and Buff.

Royal Rose.

Her Majesty-Rosy pink.

Prince of Wales-Rose crimson.

Salopian-Brilliant scarlet.

Coccinea-Scarlet.

Pride of Niagara-Pink and white.

Blanche Ferry-Extra early, pink, and white.

Maid of Honor-Bluish white.

Slialızada-Claret and maroon

Helen Pierce-Bright blue bell shapedflowering beautiful.

Countess Radnor-Lavender.

Dorothy Tenuant-Rosy mause.

Captivation-Light magneta.

And many more new and beautiful varieties.

Ricinius or Castor Oil Bean (h h a)-Very ornamental and quite tropical in appearance; much used for center plants of flower beds. A good variety is the Zanzibariansis, which surpasses in size and beauty all varieties heretofore known. The leaves are light green with whitish ribs and measuring from two to two and one-half feet across. For large groups or single specimens it is an exceedingly striking and effective ornamental foliage plant, Growing from 14 to 16 feet high.

Salpiglosis-These annuals have very showy, large funnel shaped flowers, mottled vined and self-covered; fine for beds. They require a rich soil, and will well repay liberal treatment.

Salvia Splendens-Flowering Sage. A standard and well-known bedding plant that keeps the garden bright for their brilliant scarlet flower spikes until late in the fall. Sow seeds in window boxes or frames, and set the plants in the open ground about the end of May. No plant could be finer for bedding. We recommend it highly. Per paper, $10 \mathrm{c}$. 
Sensitive Plant (t $\mathbf{a})-\mathrm{A}$ very curious and interesting plant; leaves close when touched or shaken.

Snap Dragon or Antirrhinum-The Snapdragon is one of our finest perennials flowering the first year from seed. Its brightcolored, curiously formed flowers always excite interest. The rich spikes are beautiful for cutting, and keep fresh a long time. Flower profusely through summer until frost. For early flowers, sow under glass in February or March, and transplant into beds of warm, dry soil moderately enriched. The Snapdragon is treated as an annual, and the seed sown every year. Average height, 2 feet.

Stocks (h $\mathbf{h}$ a)-German Ten Week Levkoyen-the finest German varieties, unsurpassed for brilliancy, variety of color and fragrance. Sow seed under glass in March. Transplanting several times in the early stages of growth tends to give them a more compact and dwarf habit.

Sweet William (h p)-A bed of these can hardly be surpassed in color and habit; producing large heads of beautiful colored flowers in great profusion; very effective for bedding. Admired by all.

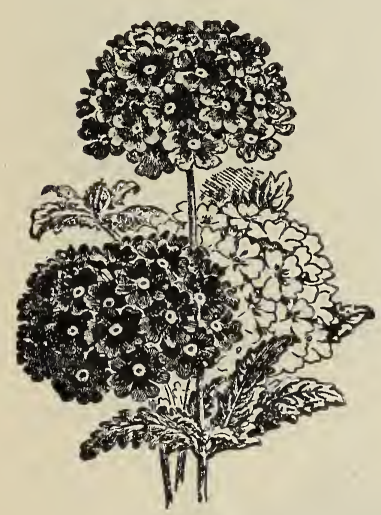

Verbena - All of this genus are extremely beautiful and ornamental, flowering profusely either as pot plants or in the g a rden. Our seeds are saved from fine named varieties and will produce healthy plants with flowers of fine colors:

Plants grown from seed are much more vig. orous than those grown from cut-

tings, and continue strong and healthy until destroyed by frost. They flower perfectly well from seed sown in spring. If started in the house in pots, during the winter, they will bloom sooner. Each plant will require a space of one-foot. Tender perennial trailer, one foot high.

The assortment we offer this season cannot be excelled:

Pure White, Scarlet, Auricula, Italian, Striped, Purple and Fordhook, the later in brilliant mixed colors.

Zinnia-Mammoth Flowering Double, 10c package. A distinct and splendid class of this ever popular flower, producing extra large, double blooms.

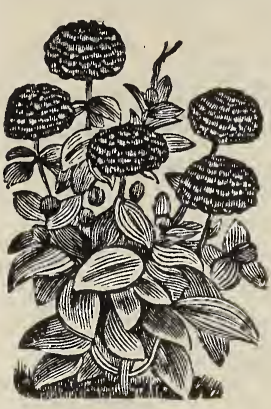

Zinnia
Zinnia (h h a)--Fine bedding and border plants, blooming long and abundantly. Beds of these are greatly admired. The colors are varied and bright, and plants are easily grown. It should be more extensively cultivated, as the varieties have been much improved of late. The collection offered will be found very choice, and are sure to give satisfaction.

Zinnias succeed best in rich deep and loamy soil, and in a sunny situation.

Mammoth Zinnias-Our strain of this magnificent large-flowered type is unsurpassed. The blooms are of immense size when well grown, averaging three and one-half inches in diameter and often three to four inches in depth.

Double Pompon-These Zinnias grow two feet high and are sturdy and bushy. They are sometimes called "Lilliput," on account of their beautiful little flowers, which are very double.

Double Dahlia-The Dahlia is the grandest autumn flower we have. Nothing is its equal in any respect in September and Octo-

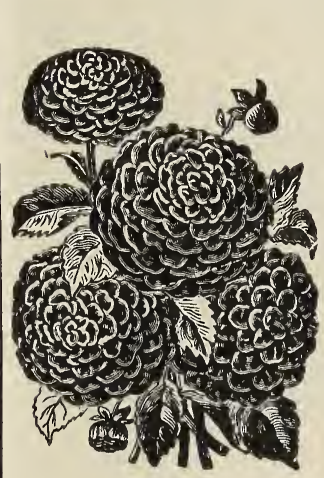

Dahlias ber. It is in its glory when every. thing else is faded or fading, and sur. renders only to the king frost. Plant tubers when the s e a s o $n$ becomes warm, covering the neck three inches. If many shoots start, thin them out.

As the Dahlia is a fall flower, there is no need of planting $\mathrm{b}$ e for $\mathrm{r}$ about the begin. ning of May or later.

These Dahlias of recent introduction are in our estimation, the finest in cultivation.

\section{POMPON OR BOUQUET DAHLIAS}

Snow Clad-The best white pompon.

Katherine Schorr-Best yellow pompon; blooms profusely until frost.

\section{DOUBLE SHOW AND FANCY DAHLIAS}

Red Husser-Brilliant currant red, full to the center, and profuse bloomer.

Storm King-Early, white, free flowering.

Queen of the Yellows-One of the best formed, and very productive yellow Dahlias.

A. D. Levoni-Clear, soft, pink; finest pink Dahlia known.

Sylvia-Shell pink.

Martin-Beautiful, large, vermillion flowers.

Lyndhurst-Large, brilliant carmine flowers. 


\section{SPRING BULBS}

\section{Gladiolus Bulbs in Mixtures}

(If any kind of bulbs are wanted by mail please add 8 cents per pound.)

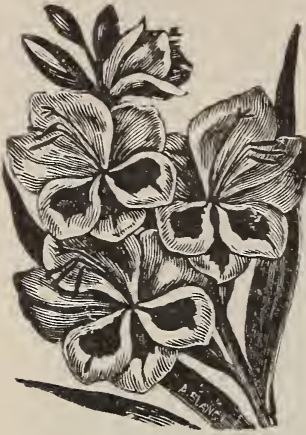

Gladiolus
$\mathrm{T} h$ is magnificent family contains hundreds of varieties, comprising all ima $\mathrm{g}$ in a ble colors, shades and variations. For cutting they are invaluable, the flowers lasting in water for a week. They can be planted at any time from May to June 15th, and never fail to flower the same season; they grow in any garden soil, commence blooming in July, and by successive planting every two weeks, can be had in flower the entire season. We keep the finest collection only.

White and light, extra fine Per Doz. Striped and variegated coc

Lemoine's fine bright colors and odd markings

Scarlet and red shades

Pink and white shades $50 \mathrm{c}$

Pink and rose shades $50 \mathrm{c}$ Blue shades $60 \mathrm{c}$ Yellow shades $60 \mathrm{c}$ Named varieties $60 \mathrm{c}$ to $75 \mathrm{c}$

\section{TUBEROSES-DOUBLE}

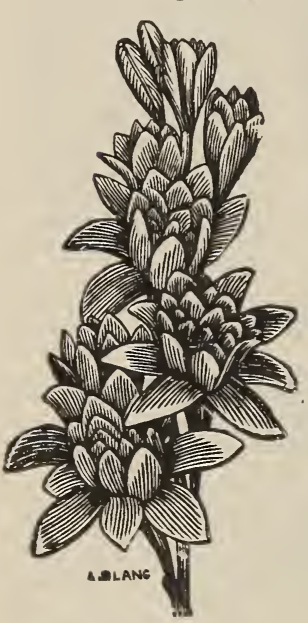

Tuberose
The Tuberose is a semi - tropical bulb and as it requires a warm and sunny situation, it should not be planted out doors until May. In cold latitudes, plant them in pots or boxes of earth, and keep them in a warm place in the house; when warm weather transplant to the garden. Previous to potting, every little side bulb should be broken off and roots cut back close to the parent bulb, as they are practically of no value. Water should be given sparingly at first until they begin to form leaves, when the quantity can be increased. When leaves are about six inches long and begin to droop over they should be cut back half their length; so as force a quicker development of the flower spike.

Doz. Each

Tall Double-Extra size bulbs $50 \mathrm{c} 5 \mathrm{c}$ Extra large bulbs - $70 \mathrm{c}$

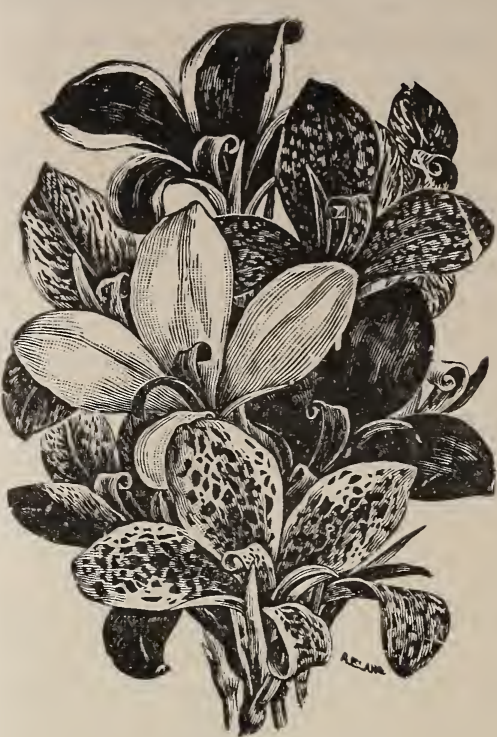

Dwarf French Cannas

But few plants are more easily managed than the Canna, when propagation and cultivation are understood. The tubers will grow almost anywhere, but prefer a very rich soil with plenty of moisture. The tubers will grow almost anywhere and under nearly all conditions, but prefer a very rich soil with plenty of moisture. The tubers should be planted singly, at least two feet apart; at this distance, in soil well suited for them, they will form a complete mass.

The new French varieties give the best satisfaction; the large size brilliant coloring of the flowers, embracing every shade of color, beautifully marked, mottled and spotted dwarf compact habit of growth, and luxuriant foliage. These improvements are so decided as to make of the French Cannas one of the grandest novelties of the day.

Without exception, there is no plant that makes a more grand, a more continuous show through the summer and autumn, and less expensive, than the French Cannas.

Indiana, *IVyoming, Austria, Allemania.

Yellow, Orange, and Variegated shades.

Pennsylvania, *King Humbert, Louisiana, Red Shades.

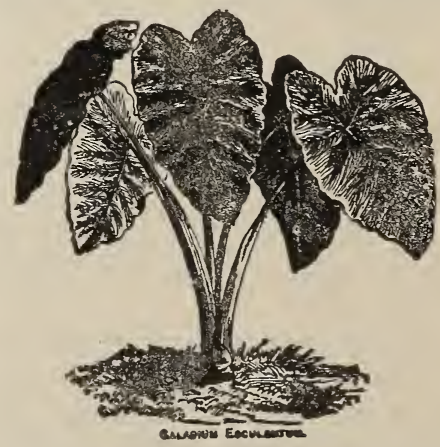

Elephant Ear-Caladium Esculentum

The Caladium is one of the handsomest of the ornamental leaved plants. There is nothing as good as the Caladium Esculentum for a grand bed of foliage in the garden. Good roots, each $10 \mathrm{c}$ to $15 \mathrm{c}$. By mail, $8 \mathrm{c}$ lb. extra. 


\section{INSECTICIDE}

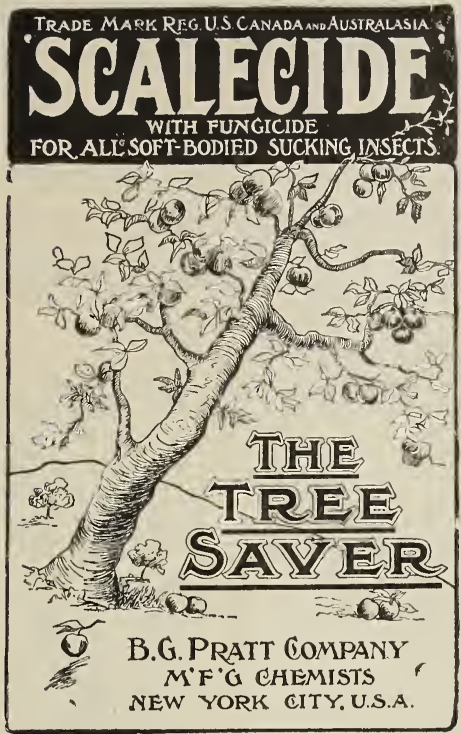

"SCALECIDE" is a petroleum oil from which the heavy lubricating and light inflammable oils have been removed, combined with certain vegetable oils and chem. ically treated so as to mix instantly and to all practical purposes permanently with cold water, making a white milky solution. It is more than an emulsion, because the oil globule is broken up, allowing it to spread further, therefore it is economy in use.

"SCALECIDE" is the nearest approach to pure petroleum soap that has ever been made, but because of its oily appearance is called a "soluble oil." This was tested out and tried by a number of the most careful fruit growers before it was put on the market for the first time in the winter and spring of 1905 .

"SCALECIDE" is more efficient, more economical, and easier to apply than any known remedy for the San Jose Scale.

Can you afford to delay longer and have your trees ruined by the "scale?" Place your order now before you forget it.

\section{PRICE OF "SCALECIDE"}

50 gallon barrels, per barrel $\$ 38.00$ 15 Gallon Drum-135 lbs. 11.50

(Drums $\$ 2.00$ extra and returnable at same price f. o. b. Factory)

Price per 10 gallons 10.60

Price per 5 gallons 6.25 Price per gallon can

\section{NIKOTEEN}

A most powerful insecticide, and when used as a spray protects plants, shrubs, blooms, trees and all foliage from the attacks of insects. Price: $25 \mathrm{c}, \$ 1.10, \$ 2.00$ and $\$ 8.00$ a bottle.
HAMMOND'S SLUG SHOT

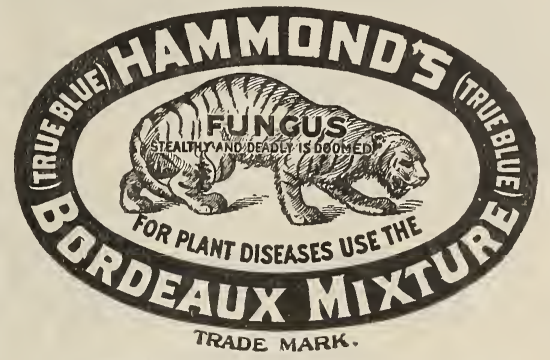

Its Efficient Is Conceded by All IVho Make Thorough Tests

It is an infallible insecticide; it is not poisonous; kills Potato Bugs, Cucumber, Melon and Squash Bugs; Currant, Cabbage, Tomato and Cutworms; Rose and Raspberry Slugs, and a good many other insects injurious to Plants, Shrubbery, etc. Pamphlet on Slug Shot. 1 lb. cans, 20c; 5 lbs., 60c; 10 lbs., $\$ 1.10$.

\section{ARSENATE OF LEAD-DRY POWDERED}

An arsenical poison used to destroy leafeating insects such as Coddling Moth (apple worm), Potato Beetle (common potato bug), Curculio (the insect that stings peaches, plums and cherries), Tussock moth, Gypsy and Brown Tail Moths (that destroy foliage on shade trees), and similar insects that feed on the foliage of fruit trees, shade trees, vegetables, flowers and shrubbery.

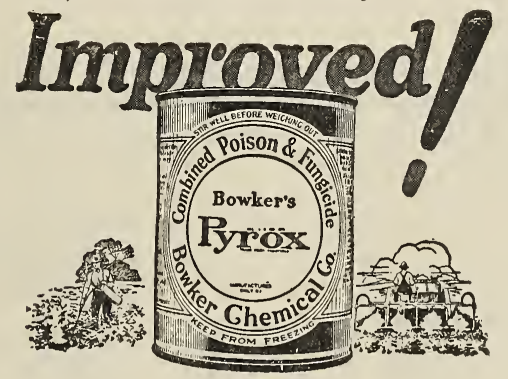

NEVER before have you had a spray material so remarkably smooth, soft, cream-like-so easy to mix, so handy, so effective as the new Pyrox.

Pyrox is the great combined insecticide and fungicide. It has no equal for killing or repelling insects and preventing blights. What's more, Pyrox improves foliage - and you know "it's the healthy top that makes the bumper crop." Ideal for home gardener and truck farmer. Jars, cans and drums.

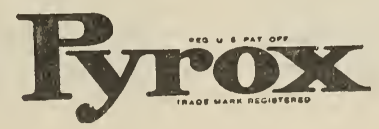




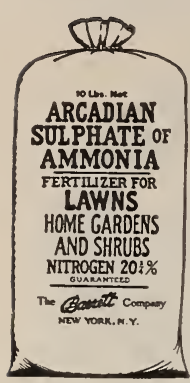

ARCADIAN SULPHATET OF AMMONIA

The best fertilizer to put on your lawn. The standard turf fertilizer at hundreds of leading golf courses and public parks. Gives a wonderful velvety growth. Discourages weeds. Easy to apply. No odor; no lumps. Full directiors in bag. Write ior free pamphlets. Price $2 \mathrm{lb}$. box, $50 \mathrm{c} ; 10 \mathrm{lb}$. bag, $\$ 2.00$.

\section{FERTILIZERS}

Commercial fertilizers are sure to come into more general use as fast as they are tried. Their quick and direct action commend them to the gardener. A customer who once buys almost invariably continues its use. The enormous quantities sold every year is an absolute proof of its utility and value to the gardener and farmer. The quantity to use per acre depends upon the crop to be cultivated and condition of soil.

\section{PURE GROCND BONE}

This article we guarantee to be strictly genuine, and an excellent fertilizer for grass lands, as well as other crops not requiring potash. It does not, however, give as quick results as bone potash, but the effect is more lasting. Harrow or drill in, using 400 or 500 pounds per acre. In planting an orchard or any kind of a tree take about 2 pounds of Ground Bone for each tree and you will surely gain one year's growth.

\section{HYDRATED LIME}

Sour or acid soil is an actual and natural condition, and Lime sweetens sour soil, just as sugar sweetens food. Weeds and water grass flourish in sour soil, but the desirable grasses will not thrive; and this is true of most of our farm crops and garden vegetables, and in general applies to all plant life.

Use Lime and grow Grass and Flowers and Vegetables, instead of weeds. You can choke out the weeds with Lime. Lime loosens up hard, sticky and compact soils, making them more porous and crumbly, permitting the roots to spread and grow, and take up nutriment from the air and water, which circulate through the loosened ground. 25c and $50 \mathrm{c}$.

\section{CONCENTRATED PULVERIZED SHEEP MANURE}

Natural Fertilizer that will give your soil all that needs to make things grow.

PURE DISSOLVED BONE PHOSPHATE

Stands without a rival as the largest crop producer, at the smallest outlay. If applied with a drill, 400 lbs., will give excellent results the same season; if applied broadcast, use $500 \mathrm{lbs}$. per acre.

\section{LAWN FERTILIZER}

Never fails to induce a rapid and rich green growth and can be applied either in the spring or fall as a top dressing. Stable dressing for lawns is objectionable in ap. pearance, odor, weed seed and cost. Our lawn fertilizer overcomes all this. $20 \times 25 \mathrm{ft}$. takes about 5 lbs.; $20 \times 50$ ft. about 10 lbs.; $25 \times 100$ ft. takes about $50 \mathrm{lbs}$; $50 \times 200 \mathrm{ft}$. takes about $100 \mathrm{lbs}$.

\section{HCMLS- "The Yeast of the Earth"}

A black or brown substance formed by decay of vegetable matter. It is unadulterated, odorless and contains no weed seed, such as are found in manure. For making new, or restoring old lawns, there is nothing equals Humus, and it is also best fertilizer for pot plants, hotbeds and garden. $25 \mathrm{c}$ and $50 \mathrm{c}$ packages.

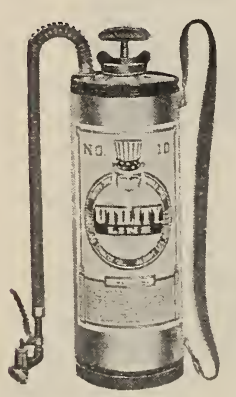

\section{USPULUN}

LSPULUN, the original organic mercury, excels through its proved selective disinfecting action on germs causing plant diseases, and also in the fact that it is harmless to higher plant life. The discovery of USPLLUN is similar to the well-known achievement in human medicine of remedies which attack disease-producins germs without injuring the cells of the body. USPLLUN has a wide range of usefulness. The pre-eminent applications are mentioned here. Many others are still in the experiment stage.

Damping-Off-USPULUN controls, without fear of injury to the Damping-Off-USPULUN controls, without fear of injury to the
growing seedlings and cuttings, this serious disease which kills growing seedlings and cuttings,
the seedlings after germination.

Seed Treatment- CSPULUN controls seed-borne diseases such as those causing root rot and ear rot of corn, cereal diseases, pea blight, etc.: increases germination; prevents molds in storage and stratification beds, and decay of seeds in the soil.

Crown Gall-USPULUN protects grafts and budded stock from this infectious disease.

Brown-Patch-CSPULUN prevents and controls this dreaded disease of golf greens, lawns, etc. A special booklet deals with this application in detail.

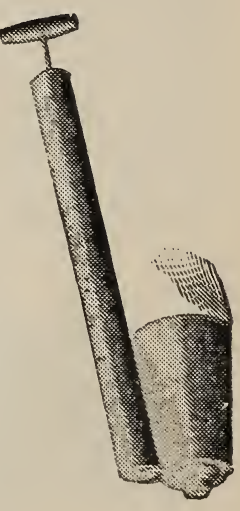

\section{A SPRAYER}

Nowadays is just as much needed as any other tool on the farm, or in the garden-for distributing Paris Green, Bordeaux Mixture, Scalecide, Kerosene Emulsion, London Purple, and all other preparations. Also for whitewashing and disinfecting poultry houses, barns, cellars, etc. 


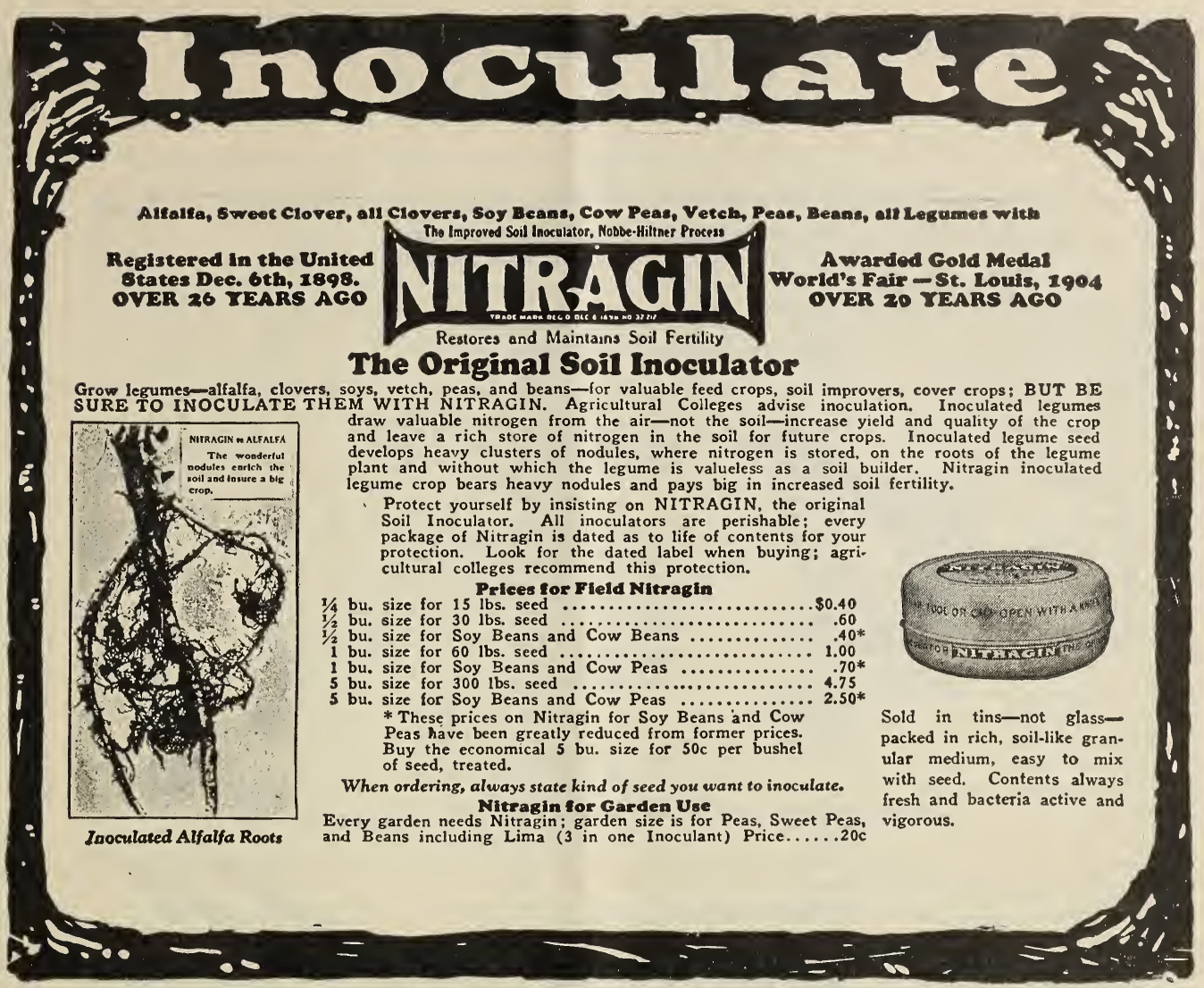

\section{Spray Plants With}

\section{EVER GREEN}

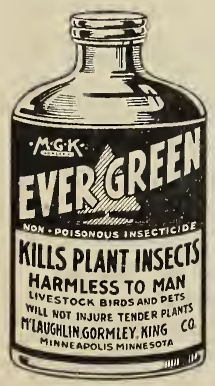

Leading entomolgists a re familiar with Ever Green and have endorsed it as a killing, effective
Kills most plant pests, including even cutworms --Use it freely on tender plants and flowers-it can't burn or otherwise injure them. Neither will it injure the soil

\section{Non-Poisonous}

EVER GREEN kills only insects-it is harmless to man, live stock, birds and pets.

Easy to Use-Just mix it with water and stirNo need for constant a $g$ i t a $t$ i $n$ g-EVER GREEN stays in solution and won't clog sprayers.

\section{LIST PRICES}

$1^{1 / 2}$ oz. bottles $\$ 0.35$ 6 oz bottles $\$ 1.00$ 1 gal bottles $\$ 13.00$ ORDER TODAY

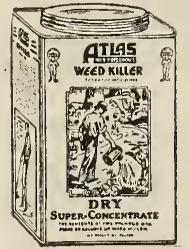

A $t$ a s Von-boisumous II ceed Killer exterminates all undesirable vegetation-including poison ivy, etc.-as easily ds watering a garden, without poison hazard to humans or animals.

Simply mix with water anc apply on any vegetationWeeds, Grass, etc., with sprinkling can or sprayer.

Especially recommended for obtaining weedfree driveways, paths, tennis courts and gutters.

DRY SUPER CONCWN'THAT' (Mailable)

Small cans (make $2 \mathrm{~T} / 2$ gals. of weed killer) _._- 50 Small cans (make 21/2 gals. of weed killer) $-\cdots$
Large cans (make 20 gals of weed killer) $\ldots$ - $\$ 2.00$

\section{LIQUID SUPER CONCENTRATTA}

5 gallon drums (will treat 2.500 sq. ft.) $\ldots$ 30 gallon drums (will treat $15,000 \mathrm{sq} . \mathrm{ft}$.) -37.50 50 gallon drums (will treat 25,000 sq. ft.) $\ldots 55.00$
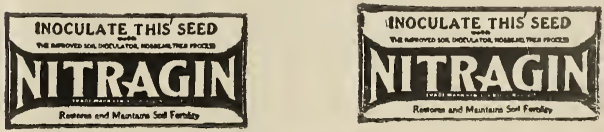


\section{What Kind, When and How to Plant and Sow Seed}

\begin{tabular}{|c|c|c|c|c|}
\hline Name of Seed & When to Plant & $\begin{array}{l}\text { How Much } \\
\text { Seed to Plant } \\
\text { in Row } 100 \text { Ft. }\end{array}$ & $\begin{array}{l}\text { Depth } \\
\text { to } \\
\text { Plant }\end{array}$ & $\begin{array}{r}\text { Apart } \\
\text { in } \\
\text { Row }\end{array}$ \\
\hline Asparagus... & April & $2 \mathrm{Oz}$ & 2 in. & $1 \mathrm{ft}$. \\
\hline Beans Bush. & April to July & 1 Quart & $2-3$ in. & 3 in. \\
\hline Lima Pole & May and June & 1 Quart & 3 in. & $4 \mathrm{ft}$. \\
\hline Beans Lima Bush & May and June & 1 Quart & 3 in. & $12 \mathrm{in}$. \\
\hline Beets. & April to July & $2 \mathrm{Oz}$ & $1 \mathrm{in}$. & 3 in. \\
\hline Cabbage Seed & April, May, June & $1 / 2$ Oz. 1000 pl'ts. & & 2 in. \\
\hline Cabbage Plants & April, May, June, July & 80 plants & & $15-18$ in. \\
\hline Cauliflower & April & 80 plants & & $15 \mathrm{in}$ \\
\hline Carrot & April to July & $1 \mathrm{Oz}$ & 1 in. & 3 in. \\
\hline Celery & April, May & $1 \mathrm{Oz}$ & $1 / 4$ in. & $12-15$ in. \\
\hline Corn Sweet. & May to July & 1 pt. 200 hills & 3 in. & $11 / 2 \mathrm{ft}$ \\
\hline Cucumber & May and June & 2 Oz. 100 hills & 1 in. & $5 \mathrm{ft}$. \\
\hline Egg Plant. & May & 60 plts. & & $2 \mathrm{ft}$. \\
\hline Endive & July and August & $1 \mathrm{Oz}$ & $1 / 4 \mathrm{in}$. & $8 \mathrm{in.}$ \\
\hline Kohlrabi & April & $1 \mathrm{Oz}$ & $1 / 4$ in. & 8 in. \\
\hline Lettuce... & Any Month Ex. Frozen & $1 \mathrm{Oz}$. & $1 / 4$ in. & 8 in. \\
\hline Leek & April & $2 \mathrm{Oz}$ & $1 / 2$ in. & 4 in. \\
\hline Water Melon & April to June & 1 to 30 hills & $1 \mathrm{in}$. & $6 \mathrm{ft}$. \\
\hline Musk Melon & April to June & 1 to 70 hills & $1 \mathrm{in}$. & $5 \mathrm{ft}$. \\
\hline Onion & April & $2 \mathrm{Oz}$ & $1 / 2$ in. & 3 in. \\
\hline Onion Sets & April and May & 2 quarts & 2 in. & 3 in. \\
\hline Peas & March and April & 1 pint & 3 in. & 2 in. \\
\hline Pepper & May & 60 plants & & $15 \mathrm{in.}$ \\
\hline Parsnip & March and April & $2 \mathrm{Oz}$ & 1 in. & 4 in. \\
\hline Parsley & April & $1 \mathrm{Oz}$ & $1 / 2$ in. & 3 in. \\
\hline Radish & March to July & $1 \mathrm{Oz}$ & $1 / 2$ in. & 2 in. \\
\hline Potatoes & March to July & $1 / 4$ peck & 4-5 in. & $12-15$ in. \\
\hline Pumpkins. & April and May & $1 / 2 \mathrm{Oz}$ & 1 in. & $6 \mathrm{ft}$ \\
\hline Squash & April and May & 6 to 8 to hill & 1 in. & $6 \mathrm{ft}$. \\
\hline Salsify & March and April & $2 \mathrm{Oz}$ & 1 in. & 3 in. \\
\hline Swiss Chard & April & $2 \mathrm{Oz}$ & 1 in. & 3 in. \\
\hline Tomato Seed & April to June & $1 / 8$ Oz. & 1 in. & $4 \mathrm{ft}$ \\
\hline Tomato Plants & April to July & 50 plants & 3 in. & $4 \mathrm{ft}$. \\
\hline Turnip_ & April to August & $1 \mathrm{Oz}$ & 12111. & \\
\hline
\end{tabular}

\section{USEFUL REFERENCE TABLE}

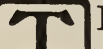

HIS TABLE gives the amount of Pure Clean Seed ONLY, and which every Farmer ought to buy. Good Fresh Seed will grow and is always the cheapest. All experienced and successful farmers recommend heavy seeding, especially wheer the soil is poor.

\begin{tabular}{|c|c|c|c|c|}
\hline & $\begin{array}{c}\text { Lbs. to } \\
\text { Bushel }\end{array}$ & $\begin{array}{r}\text { Ibs. to } \\
\text { Acre }\end{array}$ & $\begin{array}{l}\text { Lbs. to } \\
\text { Bushel }\end{array}$ & $\begin{array}{r}\text { Lbs. to } \\
\text { Acre }\end{array}$ \\
\hline Clover-Red & 60 & $8-10$ & Southern Cow Peas _____ 60 & $60-90$ \\
\hline Clover-Alsike _._. & 60 & $15-20$ & Soja Beans & $60-90$ \\
\hline Clover-Alfalfa & 60 & $15-20$ & Canada Field Peas 60 & $60-90$ \\
\hline Clover-White Dutch & 60 & 4- 6 & Kaffir Corn, broadcast & 50 \\
\hline Timothy & 45 & $10-15$ & Sorghum, broadcast & 50 \\
\hline Millet and Hungarian _. & 50 & $25-38$ & Buckwheat _._. 50 & $20-50$ \\
\hline Red Top, free from chaff & 25 & $5-10$ & Dwarf Essex Rape & 4- 7 \\
\hline Blue Grass, free of chaff & 22 & $25-50$ & Grass Mixture _......... & $20-25$ \\
\hline Orchard Grass & 14 & $20-25$ & Flax Seed 56 & 50 \\
\hline White Beans & 60 & $15-30$ & Corn in hills & 4 qts \\
\hline
\end{tabular}




\section{GARDEN TOOLS}

The continuous scarcity of labor, with its attendant poor quality and high price, has made good farm and garden tools of more importance than ever, and if you expect to be prosperous in cultivating your land and garden, you cannot be without labor-saving tools. For intsance, with a wheel hoe before you, you are in a position to push your work. With only your old-fashioned hoe, you will be pushed clear out of your garden by weeds, and take backache with you in the bargain. You can do better work in two hours-after you get the knack of handling these tools-than you can by hoeing all day.

\section{"PLANET JR." TOOLS NOTHING IS EQUAL TO THEM}

New "Planet, Jr." No. 3, Single-Wheel Hill Dropping Seed Drill-Sows either in hills or continuous rows. This seed drill has been offered widely by the manufacturers of the celebrated "Planet, Jr." goods. It has been thoroughly tested by careful gardeners and nurserymen during many seasons, and the manufacturers guarantee it to give entire satisfaction. $\$ 17.00$.

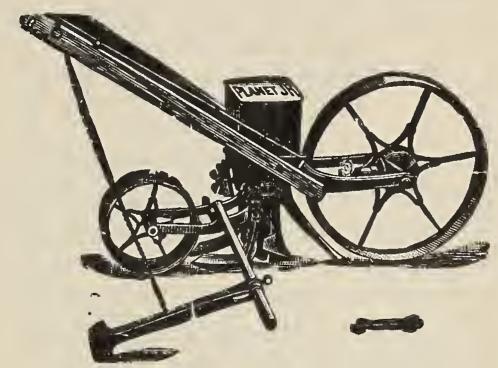

PLANET JR. 4

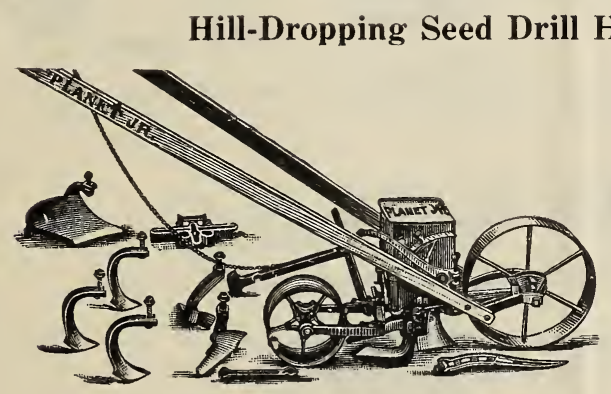

Cultivator and Plow

NO. 31 PLANET, JR.--Is a new combined tool of great value to thousands of gardeners who have never felt able to own either a seed drill or a wheel hoe. It is thoroughly wellmade and offered at a price that makes it pay the very small gardener. It will sow even a small packet of garden seed the proper thickness desired with precision from $1 / 4$ to 2 inches deep and in a narrow row. The index is simple, easily set for every kind of seed. The flow of seed is stopped by simply raising the handles and pressing the coverer down with the foot. The bottom of the hopper is open to full view. Seeds difficult to sow, like salsify, parsley, beets and lettuce, and radishes, beans, turnips, cucumbers, carrots, pickles, spinach, celery, cantaloupe, etc., are handled admirably. It holds one quart. 'The seed drill attachment may be removed in a moment and replacd as quickly by a tool standard to which are fitted all the various cultivating attachments. Price, $\$ 12.00$.

Cultivator and Plow Combined-No. 12. Has the invaluable feature of tending both sides of the row at once. The wheels can be set at four, seven or ten inches apart. It has a pair of plows, two pair of cultivator teeth and a pair of leaf lifters. making it capable of every variety of gardener's work. Price, $\$ 10.50$.

Combines conveniently in a single garden implement a capital hill-dropping and continuous row seeder with the most perthat the most practical can desire. Designed by a practical man, it is light, compact, durable and easy running, and does all its variety of work with a thoroughness nd perfection that has never been at tempted, much less equalled.

Price, complete, $\$ 17.50$; as drill only, $\$ 14.00$.

PLANET, JR., SINGLE WHEEL HOE, CULTIVATOR AND PLOW

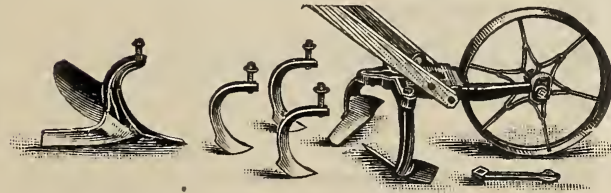

No. 17-Single Wheel Hoe-Greatly im. proved. It is the latest and best in every particular, and we recommend it as superior in many respects to any of the old styles. This is a cheap cultivator for the money and should be used more extensive. ly. Price, $\$ 7.25$. 


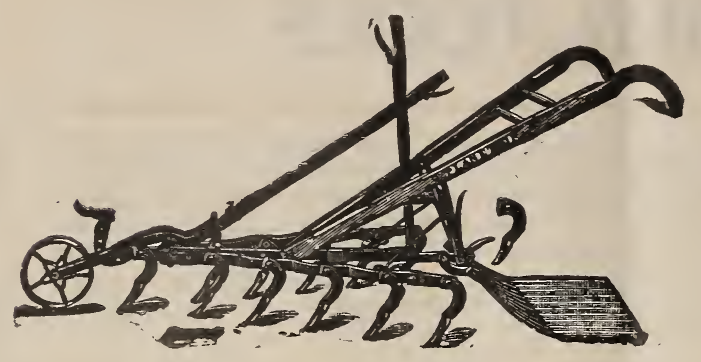

\section{The Planet Jr.}

Twelve-Tooth Harrow and

Pulverizer

A new tool for fine cultivation, deep or shallow. It has a lever wheel, lever expander and pulverizer, $\$ 17.00$.

The "Planet, Jr." Horse Hoe No. 8

Has the patent lever expander to open and shut the sides, and also a lever close at hand for raising and lowering the wheel, thus controlling the depth of working. The side levers are also changing in pattern and are now reversible and have patent plowshare points, which can be sluarpened. \$16.0c.

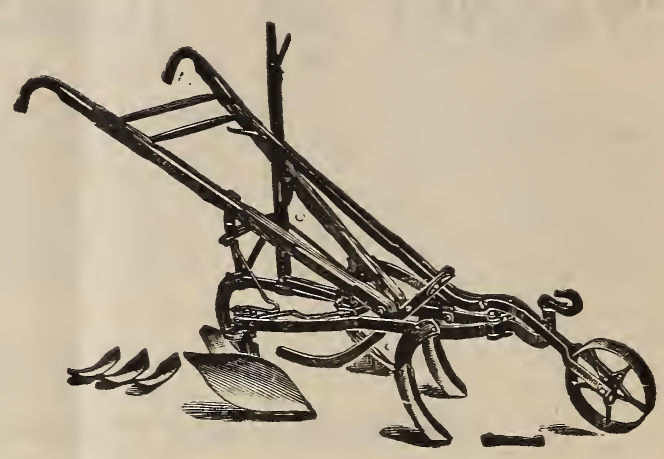

Send for illustrated "PLANET. .JR." Book-FREE on application

\section{FARMER'S No. 19}

HIGH, SINGLE WHEEL HOE CILTIVATOR AND PLOW-PRICE, \$Ẽ.06

This new and attractive implement is especially designed for the farmers' garden work. though it offers to every one with either field or garden, a cheap and effective tool for all hand wheel hoe operations. The tools are as follows: A large garden plow, 10-inch sweep, 6-inch sweep, 4-inch cultivator tool, and 12-inch tooth. The great variety and fine shape and quality of the tools make the implement valuable for many kinds of work. It is strong, well-made and can be quickly set so as to be useful, whether in the hands of a man or wom. an, boy or girl. Strength, variety of tools and cheapness are its great virtues.

LANG'S HAND WEEDER.

Undoubtedly the best Hand

Wreeder on the market.

Price, 25c. •

EXCELSIOR WEEDING HOOK

Does good work among small and tender plants. Price, $15 \mathrm{c}$.

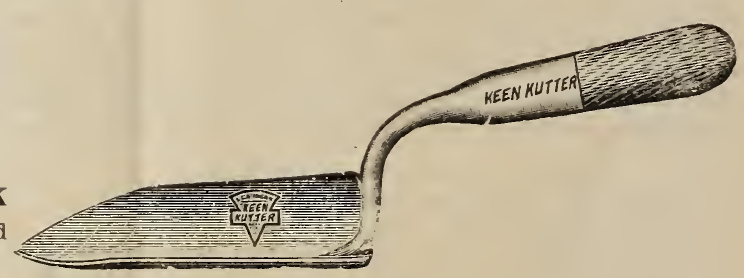

\section{PLANTING TROWELS}

of cast steel and solid shanks. Price, $15 \mathrm{c}$ to $60 \mathrm{c}$ each.

\section{BLLBS FOR FALL PLANTING}

To bloom during winter and following spring-Tulips, Hyacinths, Narcissus. Crocus. Lilies, etc. Ready October 1st.

Ask for prices. 


\section{N D E X}

\begin{tabular}{|c|c|c|}
\hline & Page & $\mathbf{P a}$ \\
\hline Asparagus & Flower Seed- & Onions _-_____ $15-16$ \\
\hline Alsike - 22 & Sowing and Culti. & Okra, or Gumbo \\
\hline Alfalfa & vation & Parsnip _.___________ \\
\hline Beans $6-7$ & Force Pumps & Parsley \\
\hline Beets $5-6$ & Forage Seeds & Peas _- \\
\hline Bluegrass & Gladiolus & Peppers _..._. \\
\hline Bordeaux Mixture _..._... 37 & Grass Seed & Potato \\
\hline Bulbs 34 & Herbs -...- & Pumpkin .... \\
\hline Cabbage $9-10$ & Hungarian & Radish $17-18$ \\
\hline Cannas 36 & Implements, Garden .....39 & Rape, Dwarf Essex _..._._23 \\
\hline Carrots 10 & Insects 37 & Reference $\mathrm{Tab}$ \\
\hline Cauliflower ....-. & Insecticides & Page _._._._Cover \\
\hline Celery & Kaffir Corn & Salsify, or Vegetable \\
\hline Clover $22-23$ & Kale, or Borecole & Oyster \\
\hline Corn Salad & Kohlrabi & Seed, How to S \\
\hline Corn $8-23$ & Lawn, Formation _... 24 & Sorghum _........... \\
\hline Cow Peas & Lawn Fertilizer …_...38 & Soja Beans \\
\hline Cress & Lawn Grass _..._. 24 & Spinach \\
\hline Cucumbers & Leek - & Squash \\
\hline Cultivators $39-40$ & Lettuce & Sugar Beet \\
\hline $\begin{array}{l}\text { Cultivation of Vege- } \\
\text { tables }\end{array}$ & $\begin{array}{l}\text { I_ice Killer } \\
\text { Mangel Wurzel }\end{array}$ & $\begin{array}{l}\text { Sweet Corn } \\
\text { Sweet Peas }\end{array}$ \\
\hline Dahlias _. 34 & Melons, Musk & Thinning Out \\
\hline Drills & Melons, Water _._._. & Timothy \\
\hline Egg Plants & Millet & Tomato \\
\hline Endive & Miscellaneous Seeds _.....23 & Transplanting \\
\hline Farm Seeds & Mushrooms & Turnip \\
\hline Fertilizers 36 & Mustard & Tuberoses \\
\hline Field Corn 36 & Novelties, Specialties _...3-4 & W'hale Oil Soap... \\
\hline
\end{tabular}

\section{Bulbs For Fall Planting}

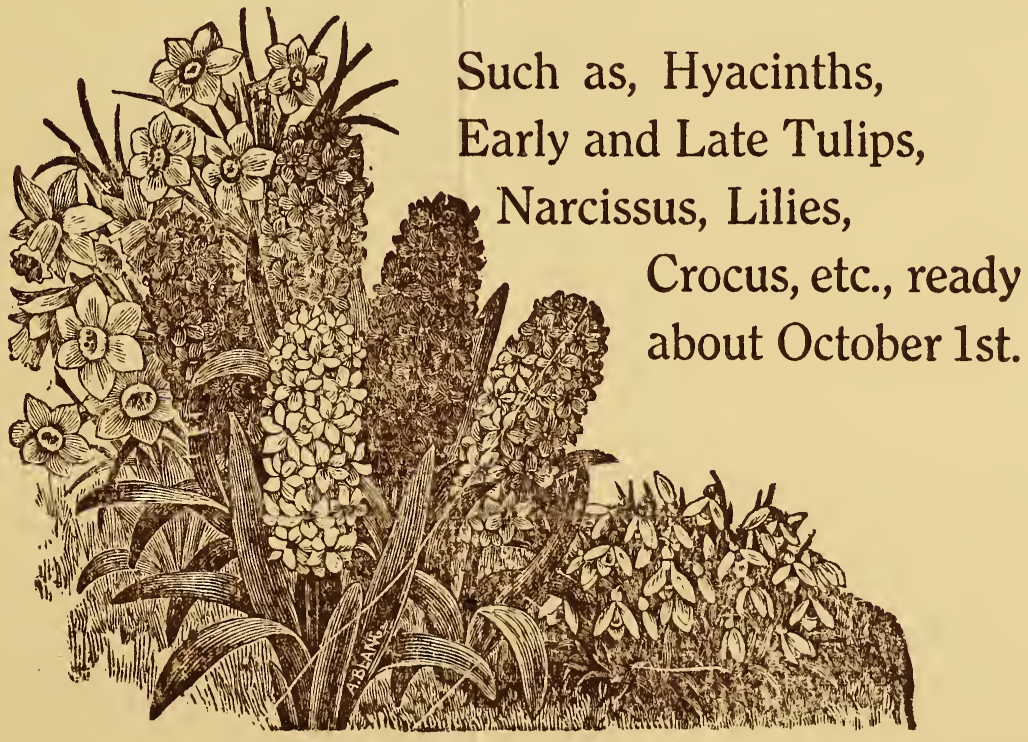

Send in your order early for $\$ 1.00$ collection. 


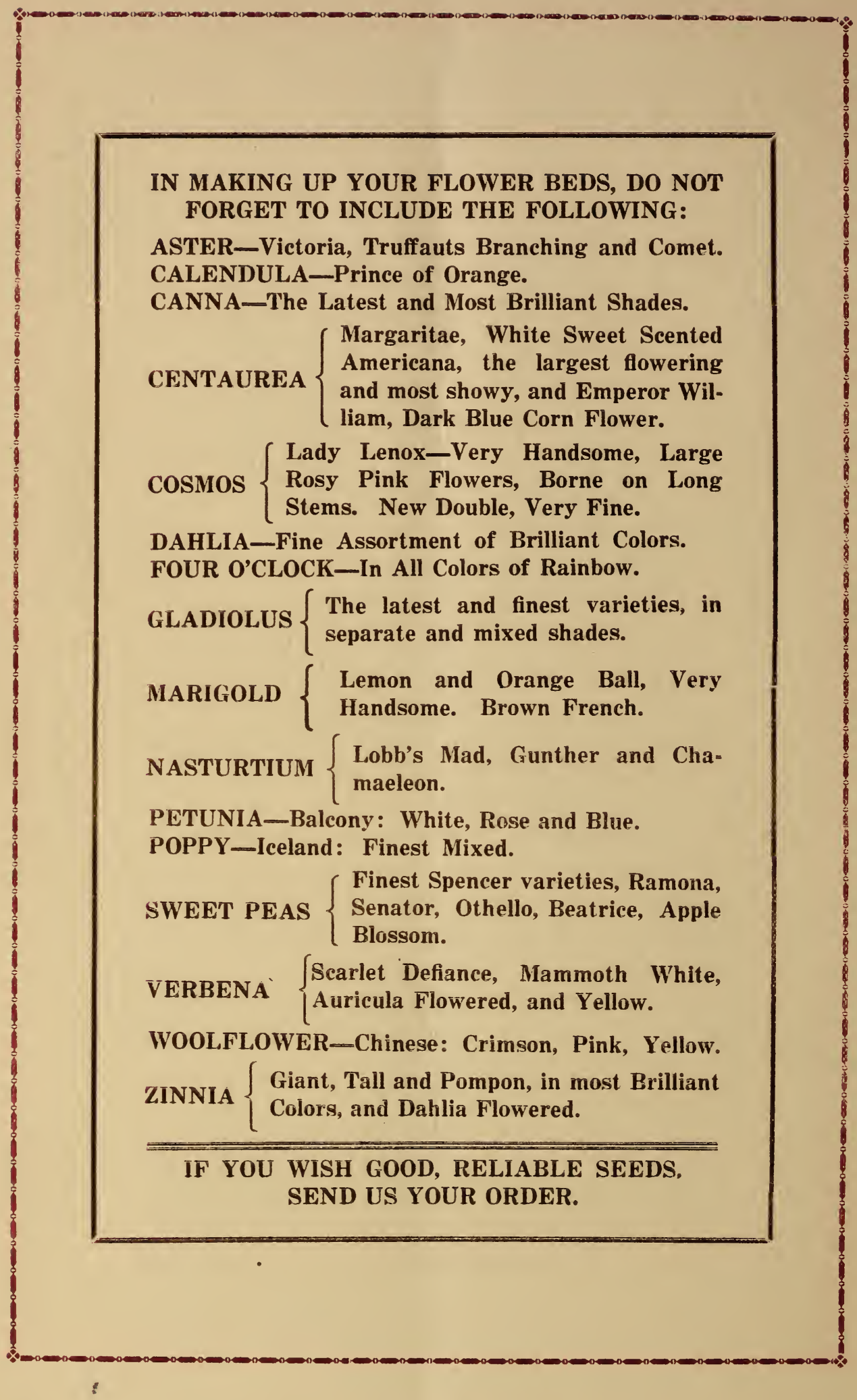

